Prepared for the U.S. Department of Energy under Contract DE-AC05-76RL01830

American Recovery and Reinvestment Act

Federal Energy Management Program

Technical Assistance Project 184 U.S. Customs and Border Protection Laboratory, Houston, Texas

$\mathrm{J}$ Arends

WF Sandusky

September 2010

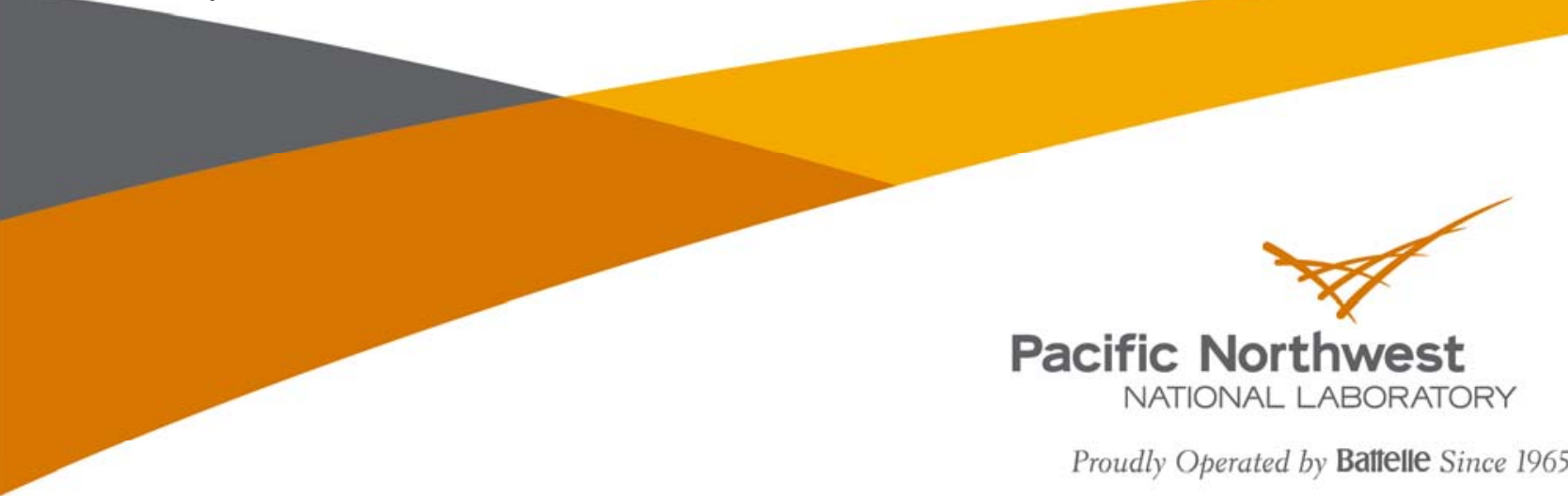




\title{
DISCLAIMER
}

This documentation was prepared as an account of work sponsored by an agency of the United States Government. Neither the United States Government nor any agency thereof, nor Battelle Memorial Institute, nor any of their employees, makes any warranty, express or implied, or assumes any legal liability or responsibility for the accuracy, completeness, or usefulness of any information, apparatus, product, or process disclosed, or represents that its use would not infringe privately owned rights. Reference herein to any specific commercial product, process, or service by trade name, trademark, manufacturer, or otherwise does not necessarily constitute or imply its endorsement, recommendation, or favoring by the United States Government or any agency thereof, or Battelle Memorial Institute. The views and opinions of authors expressed herein do not necessarily state or reflect those of the United States Government or any agency thereof.

\author{
PACIFIC NORTHWEST NATIONAL LABORATORY \\ operated by \\ BATTELLE \\ for the \\ UNITED STATES DEPARTMENT OF ENERGY \\ under Contract DE-AC05-76RL01830
}

Printed in the United States of America

Available to DOE and DOE contractors from the Office of Scientific and Technical Information,

P.O. Box 62, Oak Ridge, TN 37831-0062;

ph: (865) 576-8401, fax: (865) 576-5728

email: reports@adonis.osti.gov

Available to the public from the National Technical Information Service,

U.S. Department of Commerce, 5285 Port Royal Rd., Springfield, VA 22161

ph: (800) 553-6847, fax: (703) 605-6900

email: orders@ntis.fedworld.gov

online ordering: http://www.ntis.gov/ordering.htm

This document was printed on recycled paper.

$(8 / 00)$ 
PNNL-19653

\section{American Recovery and Reinvestment Act}

\section{Federal Energy Management Program Technical Assistance Project 184}

\section{U.S. Customs and Border Protection Laboratory Houston, Texas}

$\mathrm{J}$ Arends

WF Sandusky

September 2010

Prepared for U.S. Department of Energy

Federal Energy Management Program under Contract DE-AC05-76RL01830

Pacific Northwest National Laboratory

Richland, Washington 99352 



\section{Executive Summary}

This report documents the findings of an on-site energy audit of the U.S. Customs and Border Protection (CBP) Laboratory in Houston, Texas. The landlord for this building is Live Oak Gottesman, and the facility is leased by CBP. The focus of the audit was to identify various no-cost and low-cost energy efficiency opportunities that, once implemented, would reduce electricity and gas consumption and increase the operational efficiency of the building. This audit also provided an opportunity to identify potential capital cost projects that should be considered in the future to acquire additional energy (electric and gas) and water savings to further increase the operational efficiency of the building.

The audit identified nine measures that could be implemented immediately, resulting in a total estimated savings of 1,016 million British thermal units (MMBtu) of electrical and thermal energy that in turn would result in an annual cost savings of $\$ 14,285$. The estimated cost to implement the measures is $\$ 17,296$, so the payback for such an investment would be 1.2 years.

Two capital item projects were identified related to use of the available solar resource. These projects would result in saving an estimated additional 296 MMBtu of energy, resulting in a cost savings of $\$ 7,785$ annually. At this point, implementation of these solar projects is not cost effective unless required for increasing the amount of on-site power generation from renewable resources.

Implementation of the nine no-cost and low-cost energy conservation measures (ECMs) would decrease greenhouse gas (GHG) emissions to the atmosphere as well as create job opportunities. For the no-cost and low-cost ECMs identified, it was estimated that 81 metric tons of GHG emissions to the atmosphere would be avoided and 0.2 jobs would be created. If the renewable energy projects were implemented, 7.6 jobs would be created and 60 metric tons of GHG emissions to the atmosphere would be avoided.

If the CBP needs assistance with securing alternative financing for any identified capital project, they are strongly encouraged to contact the FEMP Federal Financing Specialist (FSS) for their region. For this site, the designated FSS is Doug Culbreth. His contact information is carson.culbreth@ee.doe.gov or (919)870-0051. 


\section{Acronyms and Abbreviations}

\begin{tabular}{|c|c|}
\hline $\mathrm{AHU}$ & Air handling unit \\
\hline ALERT & Assessment of Load and Energy Reduction Techniques \\
\hline ARRA & American Recovery and Reinvestment Act \\
\hline ASHRAE & $\begin{array}{l}\text { American Society of Heating, Refrigerating \& Air Conditioning } \\
\text { Engineers }\end{array}$ \\
\hline BAS & Building automation system \\
\hline BCS & Building control system \\
\hline BLCC & Building life cycle cost \\
\hline Btu & British thermal unit \\
\hline CBP & U.S. Customs and Border Protection \\
\hline $\mathrm{CCV}$ & Cooling coil valve \\
\hline $\mathrm{CF}$ & Cubic feet $\left(\mathrm{ft}^{3}\right)$ \\
\hline CHWST & Chilled water supply temperature \\
\hline DC & Direct current \\
\hline DDC & Direct digital control \\
\hline DOE & U.S. Department of Energy \\
\hline DP & Differential pressure \\
\hline DX & Direct expansion \\
\hline E4 & Energy efficiency expert evaluations \\
\hline ECM & Energy conservation measure \\
\hline EISA & Energy Independence and Security Act \\
\hline EPA & Environmental Protection Agency \\
\hline EPAct & Energy Policy Act \\
\hline ESET & Energy savings expert teams \\
\hline ESCO & Energy Services Company \\
\hline ESPC & Energy Service Performance Contract \\
\hline EUI & Energy Use Intensity \\
\hline $\mathrm{ft}^{2}$ & Square feet \\
\hline FEMP & Federal Energy Management Program \\
\hline GSA & General Services Administration \\
\hline IR & Infrared \\
\hline
\end{tabular}




\begin{tabular}{|c|c|}
\hline kBtu & $10^{3} \mathrm{Btu}$ \\
\hline kW & Kilowatt \\
\hline kWh & Kilowatt hour (1 kWh = $3412 \mathrm{Btu})$ \\
\hline LBNL & Lawrence Berkeley National Laboratory \\
\hline LED & Light emitting diode \\
\hline LEED & Leadership in Energy and Environmental Design \\
\hline Mcf & Million cubic feet (natural gas) \\
\hline MMBtu & $10^{6} \mathrm{Btu}$ \\
\hline NII & Non-invasive inspection \\
\hline NOFA & Notice of funding available \\
\hline O\&M & Operation and maintenance \\
\hline PM & Preventive maintenance \\
\hline PNNL & Pacific Northwest National Laboratory \\
\hline PV & Photovoltaic \\
\hline Retro-CX & Retro-commissioning \\
\hline RTU & Rooftop unit \\
\hline SHW & Solar domestic hot water \\
\hline SPV & Solar photovoltaic \\
\hline UESC & Utility energy services contract \\
\hline UV & Ultraviolet \\
\hline VAV & Variable air volume \\
\hline Yr & \\
\hline
\end{tabular}




\section{Table of Contents}

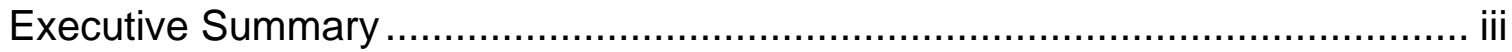

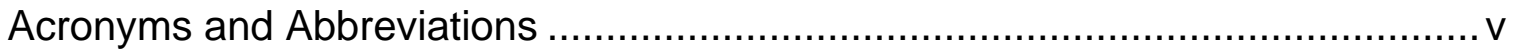

1.0 Description of ARRA Program .................................................. 1

1.1 Site Audit Activities ........................................................... 1

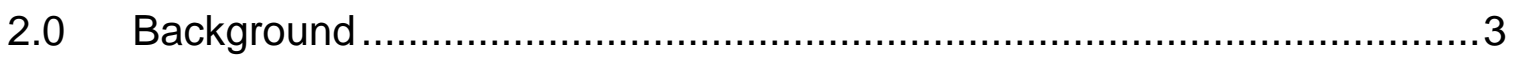

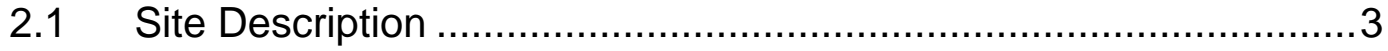

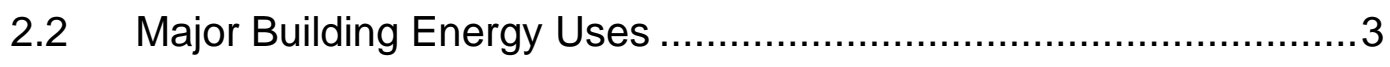

2.3 Climate, Facility Type, and Operations ................................ 5

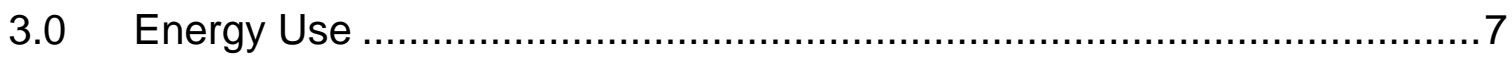

3.1 Current Electricity and Gas Use .......................................... 7

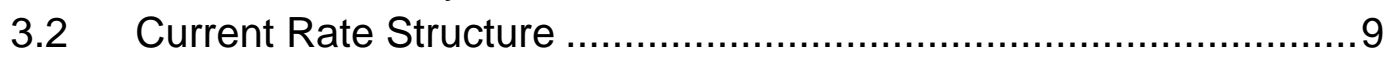

4.0 Energy Conservation Measures Identified.....................................11

4.1 Summary of Proposed Measures ........................................ 11

4.2 Summary of Other Measures Identified but not Evaluated ............18

5.0 Potential Greenhouse Gas Reduction .......................................... 21

6.0 Action Plan for Implementation of ECMs .................................... 23

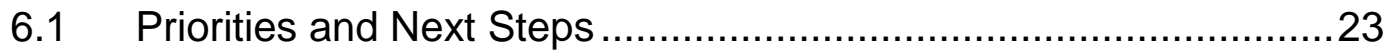

$6.2 \quad$ Funding Assistance Available .......................................... 23

7.0 Assessment Team Members and Site Team ...................................... 25

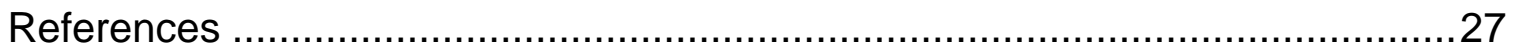

Appendix A - Model Output Files...................................................... A.

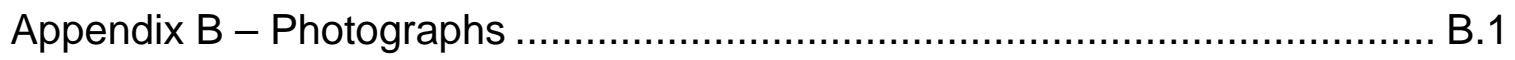




\section{Figures}

Figure 1. U.S. Customs and Border Protection Laboratory in Houston, Texas ..3 Figure 2. U.S. Customs and Border Protection Houston Laboratory Electrical

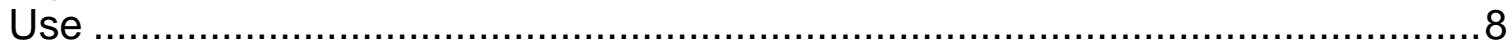

Figure 3. U.S. Customs and Border Protection Houston Laboratory Natural Gas

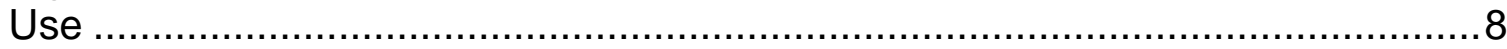

\section{Tables}

Table 1. U.S. CBP Houston Laboratory Recommended Energy Conservation

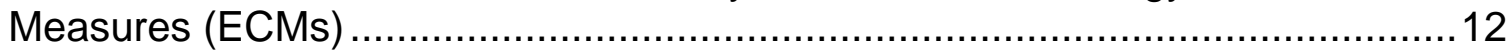

Table 2: Estimated Greenhouse Gas Reductions for Each Proposed ECM ......21 


\subsection{Description of ARRA Program}

The Federal Energy Management Program (FEMP) facilitates the Federal Government's implementation of sound, cost-effective energy management and investment practices to enhance the nation's energy security and environmental stewardship. To advance that goal and help accelerate agencies' progress, FEMP works to foster collaboration between its Federal agency customers and the U.S. Department of Energy (DOE) national laboratories.

In 2009 and 2010, FEMP has utilized funding from the American Recovery and Reinvestment Act of 2009 (ARRA) to facilitate Federal agency access to the broad range of capabilities expertise at the National Laboratories. Funds were directed to the Laboratories to assist agencies in making their internal management decisions for investments in energy efficiency and deployment of renewable energy sources, with particular emphasis on assisting with the mandates of the Energy Independence and Security Act of 2007 related to Federal facilities and fleets.

FEMP provided major DOE laboratories with funding that will allow them to respond quickly to provide technical advice and assistance. FEMP applied a simple vetting and approval system to quickly allocate work to each of the laboratories in accordance with FEMP allocated funding. All assistance provided by the Laboratory was in accordance with the requirements of Federal Acquisition Regulation (FAR) Subpart 35.017 and the Laboratories' designation as "Federal Funded Research and Development Center" (FFRDC) facilities.

The U.S. Customs and Border Protection (CBP) submitted a response to this call requesting that energy audits be conducted at both a laboratory building and a data center building in Springfield, Virginia, and a laboratory building in Houston, Texas, with the goal of identifying energy conservation measures that could be implemented in a timely manner. These requests were selected by FEMP and designated as Project 184. This report is for the CBP laboratory building located in Houston, TX.

\subsection{Site Audit Activities}

This energy and water audit was conducted using the protocols and guidance developed by Pacific Northwest National Laboratory (PNNL) to support previous FEMP activities related to assessment of load and energy reduction techniques (ALERT), energy savings expert teams (ESET), and energy efficiency expert evaluations (E4) audits at Federal sites. The primary focus of the protocols is to identify various no-cost and low-cost opportunities for major energy-consuming equipment within the building. During the audit, however, other capital cost equipment opportunities were also considered with respect to future energy efficiency projects that could be undertaken by the sites to acquire additional energy, water, and cost savings. 


\subsection{Background}

\subsection{Site Description}

The CBP Laboratory is located at 4150 Interwood South Parkway, Houston, Texas. The one-story building of 35,200 square feet $\left(\mathrm{ft}^{2}\right)$ was constructed in 2009. The facility is a state-of-the-art forensics laboratory developed and constructed for U.S. Customs \& Border Protection, and is used as a tool to help enforce import/export laws and quotas. The lab also supports investigations in criminal cases related to the illegal drug trade. The building is owned by Live Oak Gottesman and has been leased by CBP since its construction. Figure 1 is a photograph of the laboratory building.

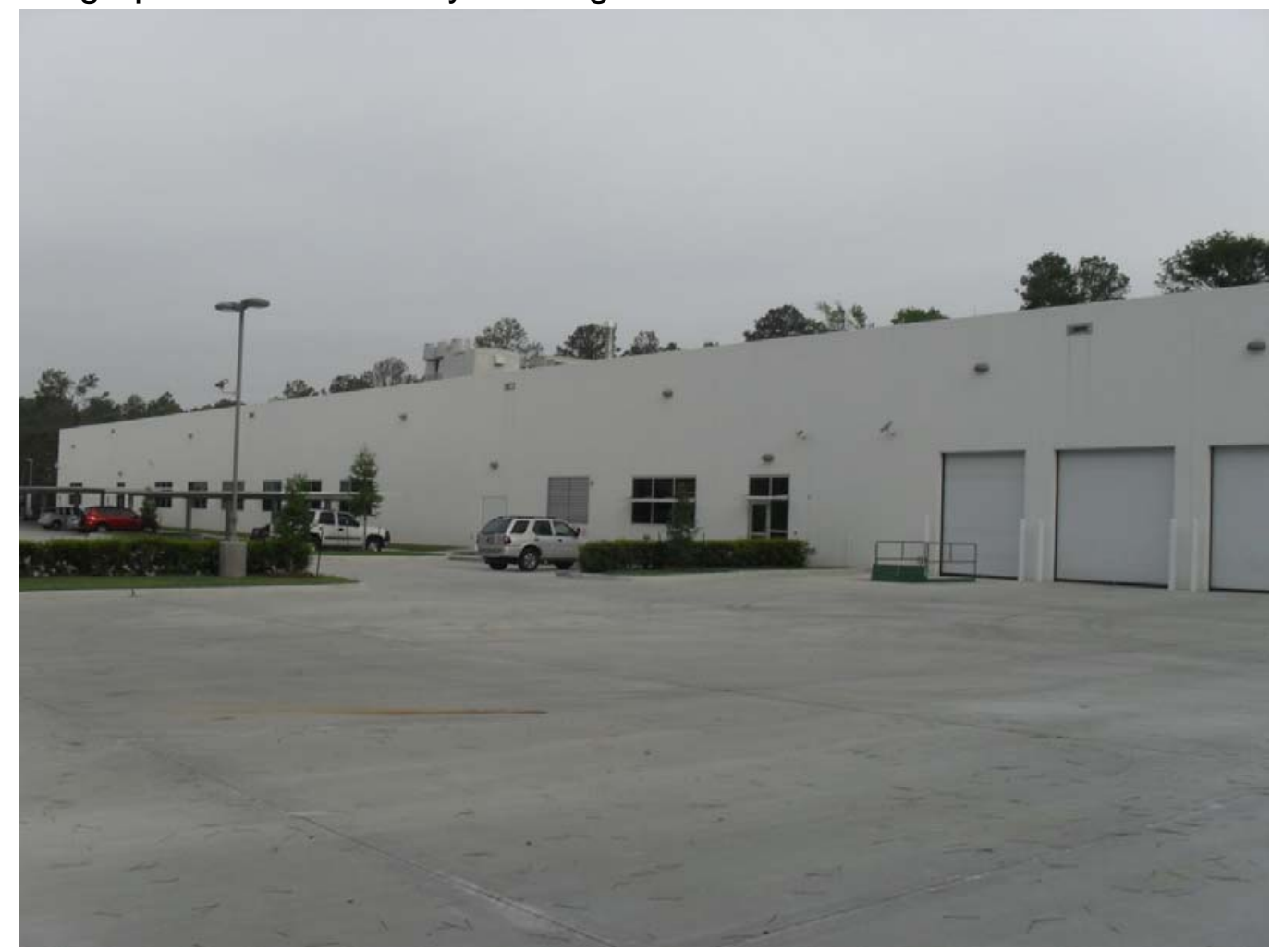

Figure 1. U.S. Customs and Border Protection Laboratory in Houston, Texas

\subsection{Major Building Energy Uses}

\section{AIR HANDLING SYSTEMS}

The building is heated and cooled by three variable air volume (VAV) air handling unit (AHU) systems with hot water heating coils and chilled water coils for cooling. AHU systems 1, 2, and 3 are located on the roof and operate continuously because the building is occupied at all times. These rooftop units (RTUs) have variable frequency drives controlling both supply and return fans. Outside air is tempered in each of the air handlers by hot water heating coils in 
the winter and by chilled water cooling coils in the summer. The AHUs deliver $55^{\circ} \mathrm{F}$ supply air via ductwork to the building terminal boxes. No humidification is provided in the AHUs.

RTU 3 serves the laboratory area of the building as a 100\% outside air system; exhaust fans pull the exhaust air from the laboratory areas. Heat recovery coils recover energy from the exhaust air of the laboratory, and this recovered energy is used to temper the outside air pulled in by RTU 3.

\section{TERMINAL UNIT DISTRIBUTION BOXES}

The perimeter zones of the building are served by VAV terminal boxes equipped with electric resistance reheat elements. Supply air for the perimeter zones is provided by VAV RTUs. Space setpoints are maintained by modulating the air volume to cool the space. If a space requires heating, the VAV box air flow is modulated to its minimum position and the electric resistance heating elements reheat the supply air to maintain space temperatures. No simultaneous heating and cooling is permitted.

The core zones of the building are also served by VAV terminal boxes. However, these VAV terminal boxes do not have reheat capability. Supply air for the core zone is provided by VAV RTUs. Space setpoints are maintained by modulating the air volume when necessary to cool the space.

\section{HEATING SYSTEMS}

A single boiler provides hot water to the building AHUs and the VAV terminal boxes. This boiler also heats the domestic hot water for the building. Waste heat from the combined heat and power (CHP) microturbines also provides heat when they are in operation.

\section{COGENERATION SYSTEMS}

Six natural gas microturbine systems provide electricity for the building and waste heat to heat building heating water and domestic hot water. Waste heat from the gas turbines is recovered from the exhaust gases with heat exchangers on three of the turbines. The water is then circulated to the building's boiler hot water loop. This additional amount of energy is used to pre-heat the ventilation air and water used for domestic applications.

\section{LABORATORY EQUIPMENT}

Laboratory equipment used in the lab includes lasers, mass spectrometers, fume hoods, and other testing apparatus. 
Office equipment is found throughout the laboratory with computers and related equipment in offices. Lighting throughout the building is provided by T-8 fluorescent fixtures, compact fluorescent lamps are used in some lobby areas; no incandescent are in use in the building. Lighting occupancy sensors and daylighting controls are currently operating in most of the offices. Daylighting controls are also used to control lighting along windows in the lab areas.

\subsection{Climate, Facility Type, and Operations}

The climate for the site is humid subtropical. Based on data available from the National Climatic Data Center, the maximum mean monthly temperature occurs in July $\left(84.5^{\circ} \mathrm{F}\right)$, with the minimum mean monthly temperature occurring in January $\left(54.3^{\circ} \mathrm{F}\right)$. The highest recorded temperature during the period from 1971 through 2000 was $108^{\circ} \mathrm{F}$ on September 4, 2000, while the lowest reported temperature during the period was $9^{\circ} \mathrm{F}$ on December 23,1989 . Based on the most recent mean data available (1971-2000), the site should experience 90 days with a maximum temperature exceeding or equal to $90^{\circ} \mathrm{F}$, while the minimum temperature should be at $32^{\circ} \mathrm{F}$ or below for 9 days. Annually, the site should anticipate 1,174 heating-degree-days and 3,179 cooling-degree-days.

Mean annual precipitation for the site is 53.96 inches. The highest daily reported precipitation was 9.95 inches for October 7,1949 . The highest reported monthly precipitation, 19.4 inches, occurred in October 1994. The daily precipitation should be at or greater than 0.01 inch for 99.1 days during the year. Mean annual snow fall for the site is 0 inch, but the highest monthly snowfall was reported in February 1994 (0.1 inch). The highest daily snow fall was 0.1 inch on February 1, 1994. 


\subsection{Energy Use}

The electrical usage is metered by Affordable Power. Two utility meters serve the building to account for the lighting; office equipment; heating, ventilation and air conditioning (HVAC); and laboratory equipment loads. Excess generation from the microturbines is not metered. There is one natural gas meter that is served by Sage Energy.

\subsection{Current Electricity and Gas Use}

The building includes office, laboratory, shop, and conference space. The building is operated continuously in the laboratory sections with a typical overall building occupancy of 25 people, although staffing levels vary during non-peak times with 10 to 15 people in the building. . Figures 2 and 3 represent energy usage since the building was completed. Water use data was not provided for the facility. The amount of purchased electricity varies throughout the year in proportion to the amount of electrical energy generated by the CHP systems. Two of the installed microturbines are dedicated to provide electricity for the laboratory equipment operation to provide reliable power in the event of utility power outages. Three microturbines with exhaust heat recovery are operated as needed to meet the thermal load of the building (however operation is limited to keep the electrical output below the electrical demand for the building). The remaining one microturbine is a backup unit. Microturbine electrical generation is maintained below or equal to the demand of the building by the microturbine controls system. The balance of electrical power used in the building is purchased from the utility. The operation of the microturbines has been very irregular since the completion of the building in June 2009 and commissioning of systems is ongoing.

Natural gas use has also been quite irregular for the same reasons the electrical use has varied during the ongoing commissioning of the natural gas mircoturbines. 


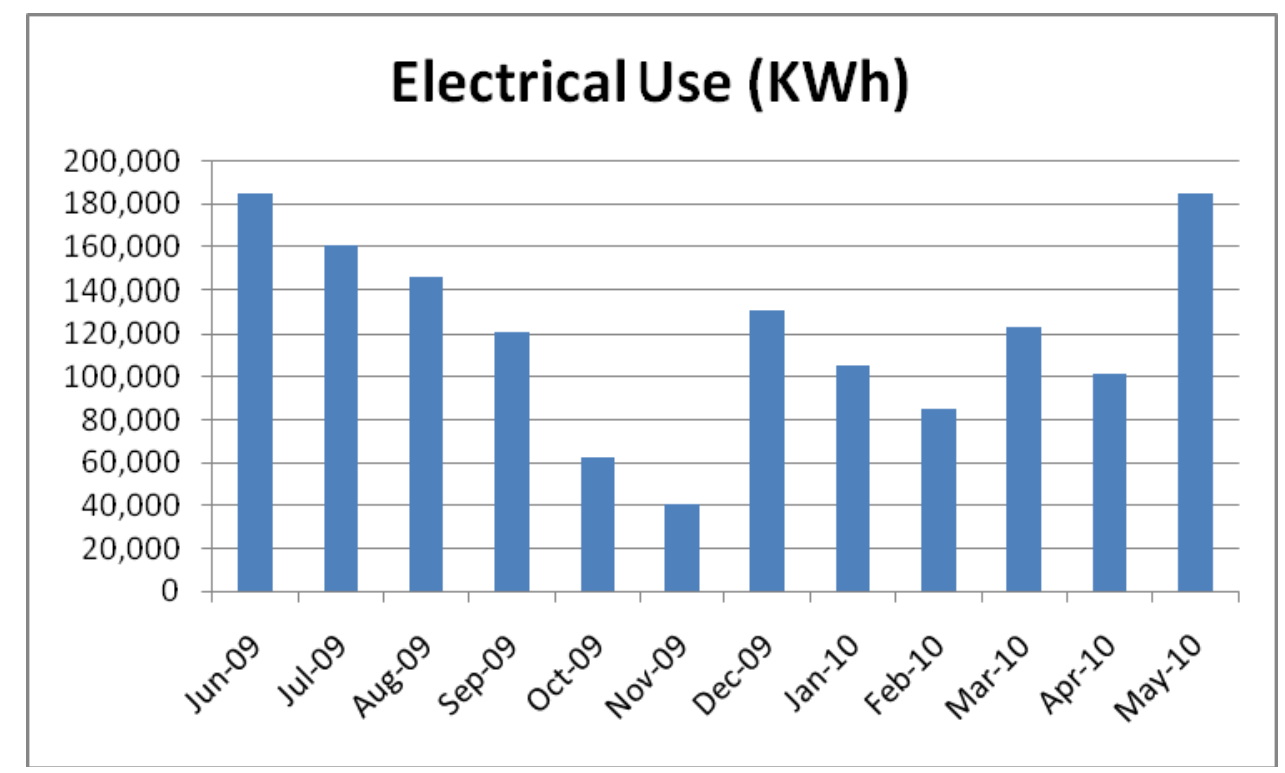

Figure 2. U.S. Customs and Border Protection Houston Laboratory Electrical Use

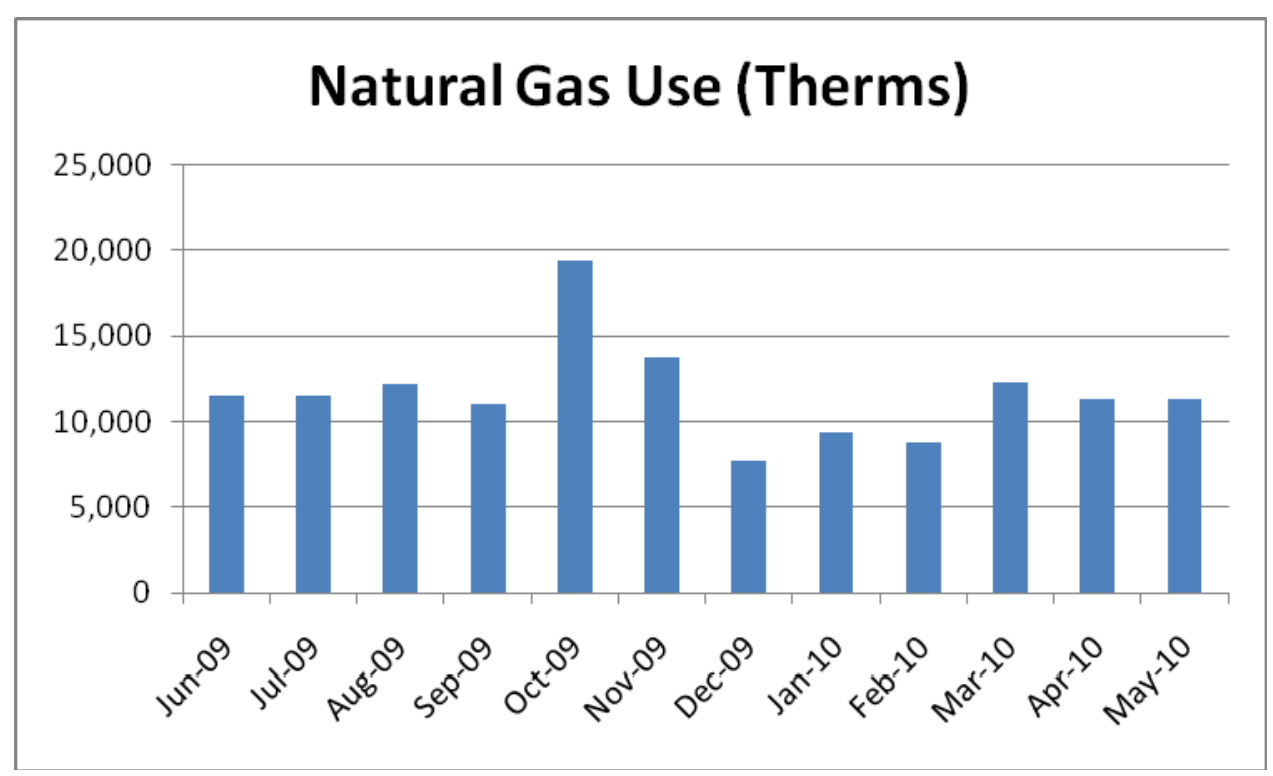

Figure 3. U.S. Customs and Border Protection Houston Laboratory Natural Gas Use 


\subsection{Current Rate Structure}

Affordable Power provides electric service under a commercial service rate. CBP currently pays an average of $\$ 0.0909$ per kilowatt hour ( $\mathrm{kWh}$ ). The current rate schedule for the building does not have a demand charge. Natural gas is provided to the site by Sage Energy. CBP pays an average of $\$ 0.558$ per therm. For water savings calculations a rate of $\$ 4$ per 1,000 gallon was used, which is typical for Houston (no water utility data was provided for the site). 


\subsection{Energy Conservation Measures Identified}

\subsection{Summary of Proposed Measures}

Nine ECMs (1 through 9) are recommended for immediate implementation. Two renewable energy measures were evaluated for a total of 11 evaluated ECMs. ECMs were evaluated in reference to annual energy and cost savings, using a simple payback method. A detailed savings summary is included in Table 1 below. Energy savings estimates are based on individual results and do not represent the interactive effect they have on each other. Savings in Table 1 are estimated reductions in energy use compared with the baseline or existing building energy usage model. The areas identified for immediate implementation were:

(1) Optimum start AHUs

(2) Holiday schedules

(3) AHU supply air temperature reset

(4) VAV AHU static pressure reset

(5) Chilled water reset

(6) Boiler heating water reset.

The following options were also evaluated:

(1) No touch automatic water faucets, urinal, and toilet fixtures

(2) Solar domestic hot water heating

(3) Solar power generation

The evaluation of the solar options did not include the impact of obtaining rebates or incentives.

The team identified (but did not evaluate in detail) the following additional possible recommendations during the visit:

(1) Dedicated chiller for laboratory X-ray unit cooling

(2) Air louvers installed in equipment yard fencing to improve chiller efficiency

(3) Rainwater catchment basin for irrigation (summer water usage data wasn't provided because the building wasn't completed until June 2009) 
Table 1. U.S. CBP Houston Laboratory Recommended Energy Conservation Measures (ECMs)

\begin{tabular}{|c|c|c|c|c|c|c|c|c|c|c|c|}
\hline $\begin{array}{c}\mathrm{ECM} \\
\#\end{array}$ & Energy Saving Recommendations & $\begin{array}{c}\text { Electrical } \\
\text { Savings } \\
\text { (kWh) }\end{array}$ & $\begin{array}{c}\text { Natural } \\
\text { Gas } \\
\text { Savings } \\
\text { (Therms) }\end{array}$ & $\begin{array}{l}\text { Energy } \\
\text { Savings } \\
\text { (Millions } \\
\text { of BTUs) }\end{array}$ & $\begin{array}{c}\text { Water } \\
\text { Savings } \\
\text { (Gallons) }\end{array}$ & $\begin{array}{l}\text { Electrical } \\
\text { Savings } \\
\text { (\$) }\end{array}$ & $\begin{array}{l}\text { Natural } \\
\text { Gas } \\
\text { Savings } \\
\text { (\$) }\end{array}$ & $\begin{array}{l}\text { Water } \\
\text { Savings } \\
\text { (\$) }\end{array}$ & $\begin{array}{c}\text { Total } \\
\text { Annual } \\
\text { Savings } \\
\text { (\$) }\end{array}$ & $\begin{array}{l}\text { Cost to } \\
\text { Implement } \\
\text { (\$) }\end{array}$ & $\begin{array}{c}\text { Simple } \\
\text { Payback } \\
\text { (Years) }\end{array}$ \\
\hline 1 & Optimum start air handling units & 3,900 & 400 & 53 & & $\$ 355$ & $\$ 223$ & & $\$ \quad 578$ & $\$ 1,200$ & 2.1 \\
\hline 2 & Holiday schedules & 900 & 100 & 13 & & 82 & 56 & & 138 & 100 & 0.7 \\
\hline 3 & AHU supply air temperature reset & 31,900 & 6,600 & 769 & & $\$ 2,900$ & $\$ 3,683$ & & $\$ 6,583$ & 900 & 0.1 \\
\hline 4 & VAV static pressure reset & 10,100 & 600 & 94 & & 918 & $\$ \quad 335$ & & 1,253 & 1,200 & 1.0 \\
\hline 5 & Chilled water reset & 10,800 & 300 & 67 & & $\$ \quad 982$ & 167 & & $\$ 1,149$ & $\$ 900$ & 0.8 \\
\hline 6 & Heating water reset & -200 & -100 & -11 & & (18) & (56) & & $\$ \quad(74)$ & 900 & -12.2 \\
\hline 7 & No touch water faucets & 0 & 300 & 30 & 93,600 & $\$$ & 167 & $\$ 3,744$ & $\$ \quad 3,911$ & $\$ 3,960$ & 1.0 \\
\hline 8 & No touch urinal valves & 0 & 0 & 0 & 11,700 & $\$$ & $\$$ & 468 & 468 & $\$ 2,034$ & 4.3 \\
\hline \multirow[t]{3}{*}{9} & No touch toilet valves & 0 & 0 & 0 & 6,989 & $\$$ & $\$$ & 280 & 280 & $\$ 6,102$ & 21.8 \\
\hline & Total (Non-interactive) & 57,400 & 8,200 & 1,016 & 112,289 & $\$ \quad 5,218$ & $\$ 4,576$ & & $\$ 14,285$ & $\$ 17,296$ & 1.2 \\
\hline & $\begin{array}{l}\text { Percent Savings (Non- } \\
\text { interactive) }\end{array}$ & $4 \%$ & $6 \%$ & $5 \%$ & & & & & & & \\
\hline & & & & & & & & & & & \\
\hline \multicolumn{12}{|c|}{ Renewable Energy Projects } \\
\hline 10 & Solar Domestic Hot Water & 0 & 42 & 4 & & $\$$ & 23 & & 23 & $\$ 2,332$ & 99.5 \\
\hline \multirow[t]{2}{*}{11} & Solar Power Generation (70 kW) & 85,387 & 0 & 291 & & 7,762 & $\$$ & & 7,762 & $\$ 700,000$ & 90.2 \\
\hline & Total Renewable Energy & 85,387 & 42 & 296 & & $\$ 7,762$ & 23 & & \begin{tabular}{ll|}
7,785 \\
\end{tabular} & $\$ 702,332$ & 90.2 \\
\hline \multicolumn{12}{|c|}{2009 Reference Data } \\
\hline & & $\begin{array}{c}\text { Annual } \\
\text { Electrical } \\
\text { Use (kWh) } \\
\end{array}$ & $\begin{array}{c}\text { Annual } \\
\text { Natural } \\
\text { Gas Use } \\
\text { (Therms) }\end{array}$ & $\begin{array}{c}\text { Annual } \\
\text { Energy } \\
\text { Use } \\
\text { (Millions } \\
\text { of BTUs) }\end{array}$ & $\begin{array}{c}\text { Annual } \\
\text { Water Use } \\
\text { (Gallons) } \\
\end{array}$ & $\begin{array}{c}\text { Electrical } \\
\text { Cost }\end{array}$ & $\begin{array}{c}\text { Natural } \\
\text { Gas Cost } \\
\end{array}$ & $\begin{array}{l}\text { Water } \\
\text { Cost }\end{array}$ & \begin{tabular}{|c|} 
Total \\
Annual \\
Utility Use \\
(\$) \\
\end{tabular} & $\begin{array}{l}\text { Total } \\
\text { Annual } \\
\text { Energy } \\
\text { Use (\$) }\end{array}$ & \\
\hline & Cost Per Unit 2009 & & & & & 0.0909 & 0.5580 & 0.0400 & & & \\
\hline & eQUEST Baseline 2009 & $1,477,800$ & 135,700 & 18,614 & & $\$ 134,332$ & $\$ 75,721$ & & NA & $\$ 210,053$ & \\
\hline & eQUEST I Actual Use Ratio & $102.2 \%$ & $96.8 \%$ & $98.2 \%$ & & & & & & & \\
\hline & Actual Baseline Use & $1,446,528$ & 140,218 & 18,959 & & $\$ 131,489$ & $\$ 78,242$ & & $\mathrm{NA}$ & $\$ 209,731$ & \\
\hline & $\begin{array}{c}\text { Actual Energy Use Intensity (EUI) } \\
\text { (BTU/SF-YR) }\end{array}$ & 140,256 & 398,347 & 538,602 & & & & & & & \\
\hline
\end{tabular}

ECM1 - AHU OPTIMUM START

Optimum start/stop is a standard option provided in the building automation system (BAS) control strategies. This control strategy starts the building systems in advance of the building occupancy to bring space comfort temperatures to occupied setpoints before the building is occupied. Each day, the start of systems is calculated by the control system to determine how much time is needed to bring the space temperatures to the desired setpoint. Currently, the building systems are started at the same time each day on a set time schedule. Energy savings can be gained by automatically adjusting the daily start time to barely meet the requirements of the building. This strategy only applies to the offices because the laboratories operate continuously.

An eQUEST energy model was developed (Appendix A), and the estimated annual energy savings is summarized in Table 1.

ECM2 - AHU HOLIDAY SCHEDULES

The BAS has not been set up to operate the building in the unoccupied mode during holidays. Many of the laboratory areas may require occupied control of 
temperatures even on holidays. However, the non-critical areas of the building, such as offices, conference rooms, and other similar areas, could be scheduled to unoccupied operation during holiday periods. Occupancy sensors and daylighting controls are currently operating in most of the offices.

An eQUEST energy model was developed (Appendix A), and the estimated annual energy savings is summarized in Table 1.

\section{ECM3 - SUPPLY AIR RESET}

The supply air temperature for a single-duct VAV system is usually set at a constant $55^{\circ} \mathrm{F}$. This setpoint is used in the design of air handling systems to calculate the maximum air flow to satisfy the maximum cooling load conditions. If the setpoint is left at $55^{\circ} \mathrm{F}$, significant reheat will occur in the winter when air flows reach their minimums and the heating load increases. The system is in a heating mode, and the supply air temperature is often reset upward to minimize simultaneous cooling and heating. The reset schedule can be based on either return air temperature or outside air temperature. Resetting the supply air temperature not only affects the cooling and heating energy consumption, but also the fan power consumption. If the supply air is reset too high, it may result in a fan power consumption penalty.

Air handling systems that serve both the core areas of the building and the perimeter areas of the building have limited opportunities to use supply air reset control strategies. This limitation is most evident in the winter, when the perimeter zones are in heating and the core areas of the building continue to require cooling. If the supply air temperature is reset upwards, the core area VAV terminal boxes will increase air flows to maintain space temperature. This increase in air flow will cause an increase in fan energy. For a net energy savings, this increase in fan energy use would have to be offset by the energy savings in the perimeter zones that would be required for less reheating at the terminal boxes. The optimal supply air temperature needs to take into account the thermal and electrical energy costs to achieve the minimum total operating costs. Generally, the amount of reset is limited by the percent of building area included in the core areas of the building; perimeter areas are affected by the weather and present greater opportunities for temperature reset. Significant energy saving opportunities can be gained if the building perimeter and core zones are served by separate VAV air handling systems.

Maintenance staff at the lab has received many complaints about cold drafty air during the winter months indicating a supply air temperature of $55^{\circ} \mathrm{F}$. These complaints indicate the VAV boxes throttle back to minimum flows in the winter during heating, and the supply air diffusers do not distribute the air as effectively with low air flow velocities. This cold air tends to drop down around the occupants, and complaints will be registered with the operations staff. Resetting 
the supply air upwards will reduce comfort complaints. The most common supply air reset schedules vary the supply temperature between $55^{\circ} \mathrm{F}$ and $65^{\circ} \mathrm{F}$.

An eQUEST energy model was performed (Appendix A), and the estimated annual energy savings are summarized in Table 1. The energy-efficiency measure wizard option for supply air reset $\left(55 / 65^{\circ} \mathrm{F}\right)$ based on zone loads was used for these estimates.

\section{ECM4 - AHU StATIC PRESSURE RESET}

Air static pressure in a VAV air handling system is normally maintained by modulating the speed of the fan. Air is distributed throughout the building by ductwork, and VAV terminal boxes control the flow of cool air delivered to the space they serve. As the space cooling load increases, the flow of cold air increases to maintain the space temperature. If space cooling loads decrease, the requirements for cold air flow to cool the space decrease. The air flow to the VAV terminal boxes is delivered at a system static pressure. The static pressure level is established by the minimum pressure required for the terminal boxes to deliver full cooling flows.

During the winter, air flow requirements drop to their minimum levels, and the static pressure required at terminal boxes decreases. This reduced air flow requirement brings about an opportunity to reduce the system static pressure levels along with reducing energy usage. Static pressure reset control strategies have been in use for more than 20 years and have been proven to provide significant levels of energy savings.

Implementation of the improved air static pressure reset control can greatly increase the energy savings. Since 1999, American Society of Heating, Refrigerating, and Air Conditioning Engineers (ASHRAE) Standard 90.1 (ASHRAE 2007) has required that static air pressure be reset for systems with direct digital controls (DDCs) "i.e., the setpoint is reset lower until one zone damper is nearly wide open." However, system design deficiencies often limit the potential energy savings. These design deficiencies create problem zones that cause the reset scheme to underperform because they frequently or constantly generate zone pressure increase requests.

\section{Common causes are:}

- $\quad$ Undersized VAV box because of improper selection in the design phase, or because unexpectedly high zone loads are added to the space after construction;

- Cooling thermostat setpoint below design condition; 
- $\quad$ Thermostats with heat releasing equipment under them (typically microwaves and coffee pots);

- $\quad$ Air distribution design problems - high-pressure drop fittings or duct sections.

The first three items cause the zone to frequently demand maximum or nearmaximum zone air flow rates. Depending on zone location relative to the fan, a constant demand for high air flow rates indirectly causes the zone to generate frequent or constant pressure requests. The fourth problem directly results in pressure requests: for example, a zone with a fire or smoke damper installed in the 6-inch (150-millimeter [mm]) high-pressure duct at the box inlet. Small smoke dampers have little free area, so pressure drop will be high.

Ways to mitigate the impact of problem zones on static pressure reset control sequences include:

- $\quad$ Exclude the problem zones from the reset control sequence. They can be excluded by ignoring the problem zone's pressure requests or including logic that ignores the first few pressure requests. Of course, ignoring the zone results in failure to meet zone air flow and temperature setpoints. This failure may be acceptable if the zone is a problem because the temperature setpoint is too low, but it clearly can be an issue if the zone is more critical.

- $\quad$ Limit thermostat setpoint adjustments to a range that is close to space design temperatures. Direct digital control (DDC) systems typically have the ability to limit the range; occupants can adjust setpoints from the thermostat. This means of mitigation can prevent cooling setpoints that are well below design conditions.

- $\quad$ Request that all thermostats are free of impact from appliances directly under them.

- $\quad$ Fix duct restrictions and sizing issues. This choice is clearly better than ignoring the zone and letting it overheat, but the cost to make revisions may be higher that the owner is willing to invest. It is best, of course, to avoid these restrictions in the first place. For instance, avoid using flexible duct at VAV box inlets, avoid oversized inlet ducts when they extend a long way from the duct main, and avoid small fire/smoke dampers in VAV box inlet ducts.

- $\quad$ Add auxiliary cooling to augment the VAV zone. If the problem results from an undersized zone or unexpectedly high loads, a second cooling system, such as a split air conditioning (AC) system, can be added to 
supplement the VAV zone capacity. However, this solution is also expensive.

An eQUEST energy model was developed (Appendix A), and the estimated annual energy savings is summarized in Table 1. The energy-efficiency measure wizard option to model static pressure reset is not included in the current version of eQUEST. The magnitude of energy savings was estimated by modeling the baseline VAV system as a forward-curved fan system with inlet vane dampers and the static pressure reset option was modeled as a standard VAV system with variable speed drives.

\section{ECM5 - ChILLED WATER TEMPERATURE RESET}

The minimum chilled water temperature of the chiller is needed when the cooling load is at its maximum. The chiller efficiency is lowest when the chiller is fully loaded and producing its coldest chilled water (often as cold as $41^{\circ} \mathrm{F}$ ). During periods of reduced loads, the cooling systems of the building are capable of meeting cooling requirements with chilled water as high as $54^{\circ} \mathrm{F}$. Many chilled water systems are operated at a constant chilled water supply temperature even though the cooling loads vary. The chilled water temperature setpoint for the laboratory was set at $41^{\circ} \mathrm{F}$ as observed during the site visit. Therefore, energy savings can be gained by resetting the chilled water supply temperature upward as the chiller load decreases. Generally, the chiller efficiency increases by about $1.5 \%$ for each ${ }^{\circ} \mathrm{F}$ increase in chilled water temperature.

Chilled water reset control strategies maintain the chilled water supply temperature (CHWST) at the setpoint, which ranges from $44^{\circ} \mathrm{F}$ to $54^{\circ} \mathrm{F}$, by modulating chiller capacity. The CHWST will have a default of $44^{\circ} \mathrm{F}$. In a variable flow pumping system, the chilled water temperature will be reset upward only when the secondary pumps are at their minimum speeds. They are reset upward only at this point because lowering pump speed with the differential pressure (DP) reset strategy competes with CHWST reset, but DP reset will save more energy than resetting the chilled water temperature up.

When the pump speed is at the minimum allowed, the CHWST reset routine is started and continues until one or more pumps are operating above their minimum speed, and then holds the CHWST setpoint at that level until the pumps return to their minimums. A differential or time delay is included to prevent excessive over-response of the control logic. Likewise, the CHWST setpoint will not be reduced until all secondary pumps are at their maximum speed. This deference to the pressure reset is accomplished by starting the pressure reset downward when all coiling coil valves (CCVs) are less than $90 \%$ open and by not starting the CHWST reset upward until all CCVs are less than $80 \%$ open. When properly enabled, the CHWST reset sequence is when all CCVs are less than $80 \%$ open, the CHWST setpoint is at its highest value of a 
proportional range $\left(54^{\circ} \mathrm{F}\right)$; when three or more CCVs are $80 \%$ or more open, the CHWST setpoint is at its lowest value $\left(44^{\circ} \mathrm{F}\right)$.

An eQUEST energy model was performed (Appendix A), and the estimated annual energy savings are summarized in Table 1. The energy-efficiency measure wizard option in eQUEST includes an option for chilled water temperature reset control of chillers. The chilled water reset controlled by building loads was selected.

\section{ECM6 -BOILER HEATING WATER RESET}

The temperature of the hot water supplied to reheat systems in air handling systems is often required to be as high as $180^{\circ} \mathrm{F}$. The setpoint for the laboratory was originally set at $180^{\circ} \mathrm{F}$ but was reduced to $170^{\circ} \mathrm{F}$ because of difficulties in operating the CHP systems heat recovery units. This temperature was used in the design of the building systems to meet the maximum heating loads of the building. The requirements for reheat water vary as the outside air temperature varies. During reduced heating loads, the system will provide adequate heating with reheat water temperatures as low as $140^{\circ} \mathrm{F}$ when the outside air temperature is $60^{\circ} \mathrm{F}$. Therefore, many systems are set up to provide $180^{\circ} \mathrm{F}$ reheat water when the outside air temperature is at or below $0^{\circ} \mathrm{F}$, and incrementally lower the reheat water temperature to $140^{\circ} \mathrm{F}$ when the outside air temperature is at $60^{\circ} \mathrm{F}$.

The boiler installed during construction in 2009 has an efficiency of $90 \%$ and was reported during the commissioning of the boiler. An eQUEST energy model was performed (Appendix A), and the estimated annual energy savings are summarized in Table 1. There is a slight increase in energy use with this ECM, but this is compensated by extending the life of the boiler.

\section{ECMs 7 - No TOUCH AUtomatic WATER FAUCETS}

No touch solar (instead of battery) operated sink faucets have 0.25 gallon per cycle operation and also promote sanitary conditions in the bathroom.

An energy cost calculator was used (Appendix A), and the estimated annual energy savings are summarized in Table 1.

\section{ECMS 8 - No TOUCH AUTOMATIC URINALS FIXTURES AND TOILET}

No touch urinals are always flushed, odor-free, and presentable. An infrared sensor and solenoid valves activate water flow and eliminate crosscontamination from touching fixture handles. It also helps to control the spread of infectious diseases. A 0.5 gallon per flush version of the urinal flush valve is recommended to replace the existing 1.0 gallon per flush urinal valves. 
An energy cost calculator was used (Appendix A), and the estimated annual energy savings are summarized in Table 1.

ECMs 9 - No TOUCH AUTOMATIC TOILET FIXTURES

No touch toilets are always flushed, odor-free, and presentable. An infrared sensor and solenoid valves activate water flow and eliminate crosscontamination from touching fixture handles. It also helps to control the spread of infectious diseases. A 1.28 gallon per flush version for the toilet are recommended to replace the existing 1.6 gallon per flush toilet valves.

An energy cost calculator was used (Appendix A), and the estimated annual energy savings are summarized in Table 1.

ECM10 - Solar DOMESTIC Hot WATER HEATING

Domestic hot water is currently used in bathrooms, the laboratory, and in the break area kitchens of the building. Solar collectors could be mounted on the roof of the building to provide solar heating of domestic hot water. Estimates of solar water heating were obtained using the RETScreen energy modeling spreadsheets (Appendix A), and the estimated annual energy savings are summarized in Table 1.

\section{ECM11 - SOLAR POWER GENERATION}

Open space on the rooftop area of the building could be used to install solar panels to generate electricity. The space available is limited because of the presence of the RTUs. Photovoltaic (PV) panels should not be sited in areas where the panels may be shaded. Estimated electrical production for a 70 kilowatt (kW) array was obtained using the online PV Watts calculator (NRC 2010) with results provided in Appendix A. The estimated annual energy savings are summarized in Table 1. The size of the array is limited by the available roof area because the minimum electrical demand in the building far exceeds $70 \mathrm{~kW}$.

\subsection{Summary of Other Measures Identified but not Evaluated}

\section{DEDICATED CHILLER FOR LABORATORY X-RAY UNIT COOLING}

An X-ray machine is currently connected to the building chilled water loop. When the chilled water system has an intermittent loss of flow, the X-ray machine lamp often fails - at a cost of $\$ 70,000$. A dedicated direct expansion (DX) water chiller should be installed to provide backup for the building chilled water flowing to the 
unit. Sensors would start the backup DX chiller when temperatures rise above an acceptable setpoint.

Install Air LoUVERS in EQUIPMENT YARD FENCING TO IMPROVE CHILLER EFFICIENCY

The energy efficiency of the chillers could be improved if the metal panels on the north and south sides of the fence were replaced with metal panels that allow air to flow through the equipment yard. Currently air may be entrained in the equipment yard with elevated temperatures that reduce the chiller efficiency. The manufacturers' technical data for the chillers estimates a potential reduction in efficiency of up to $2 \%$ due equipment yard air flow restrictions.

\section{RAINWATER CATCHMENT BASIN FOR IRRIGATION}

Runoff water from the roof of the building could be collected in a water basin and reused to water grass and plants around the building. When runoff water is reused, it must be filtered to prevent plugging the sprinklers or drip irrigation nozzles. The irrigation piping needs to be separated from the building domestic water system. The State of Texas offers property tax exemption for commercial installations (State-wide exemption) that the owner of the leased building may benefit from the installation. For more information see the State of Texas website at:

http://www.twdb.state.tx.us/publications/reports/rainwaterharvestingmanual 3rde dition.pdf 


\subsection{Potential Greenhouse Gas Reduction}

The proposed ECMs will reduce greenhouse gas (GHG) emissions. All reported calculations in Table 2 below are based on the U.S. Environmental Protection Agency (EPA) GHG emissions calculator and are reported as carbon dioxide equivalent $\left(\mathrm{CO}_{2} \mathrm{e}\right)$. The EPA calculator estimates for kilowatt hour $(\mathrm{kWh})$ savings are based on $\mathrm{CO}_{2}$ only. If the recommended ECMs are implemented, the actual kWh savings can be used to estimate GHG emissions reductions using the EPA eGRID model (Pechan 2008), using actual data from the specific electricity provider, which takes into consideration complex factors such as the utility generation mix from coal, natural gas, nuclear, and renewable energy sources.

Table 2: Estimated Greenhouse Gas Reductions for Each Proposed ECM Reference: http://www.epa.gov/rdee/energy-resources/calculator.html

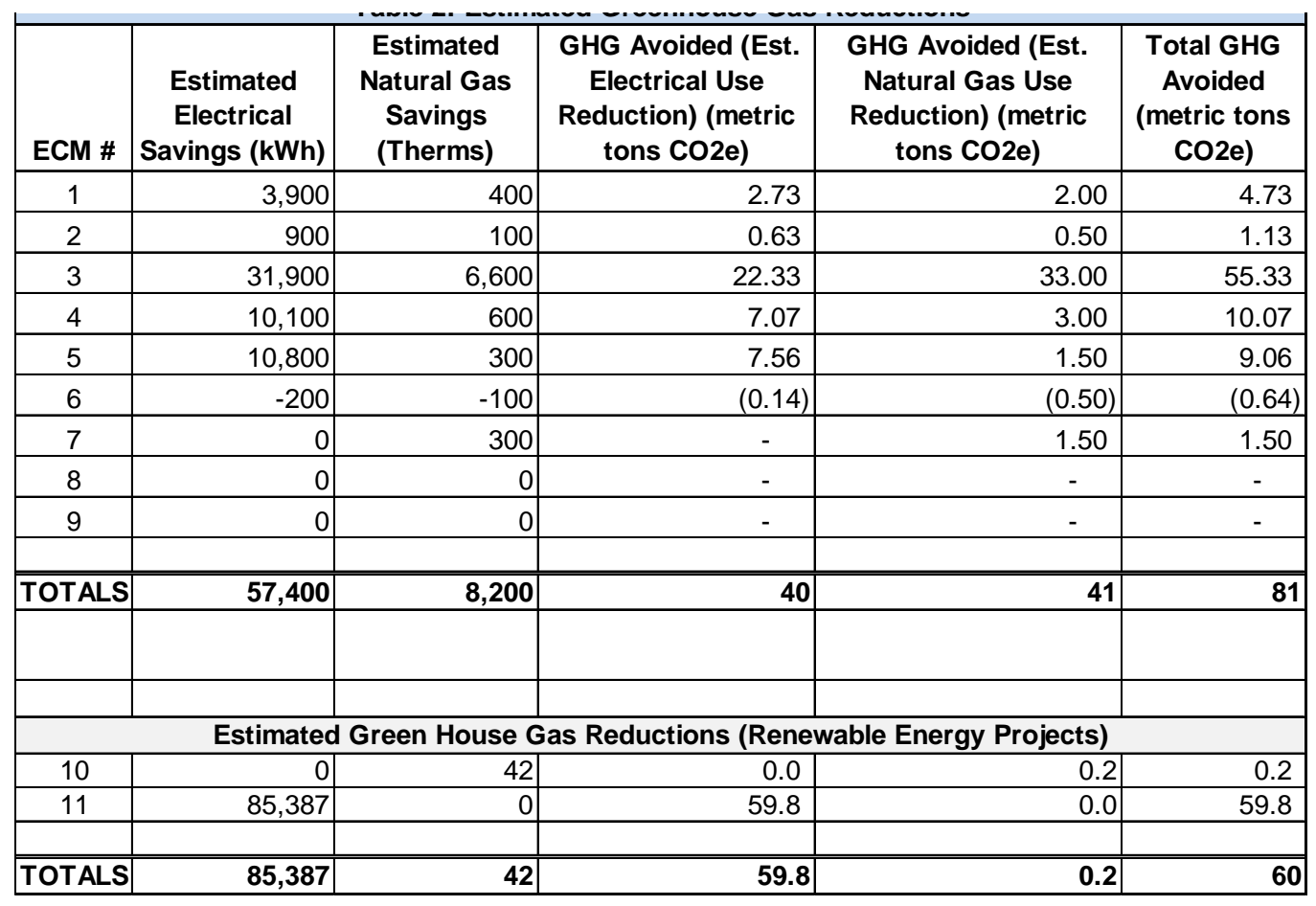

To calculate jobs created and retained, one job for every $\$ 92,000$ in funds expended was assumed. The baseline non-interactive energy efficiency retrofits $(\$ 17,296)$ will result in 0.2 job created and 81 metric tons of $\mathrm{CO}_{2} \mathrm{e}$ emissions avoided. If the proposed renewable energy projects are implemented, the estimated investment would be $\$ 702,332$. This amount would result in 7.6 jobs created and 60 metric tons of $\mathrm{CO}_{2} \mathrm{e}$ emissions avoided. 


\subsection{Action Plan for Implementation of ECMs}

\subsection{Priorities and Next Steps}

There are three ways to implement the recommended measures:

- Use the audit report findings to immediately implement the no-cost and low-cost ECMs identified.

- $\quad$ Further analyze ECMs with moderate cost or longer simple payback times.

The first action item should focus on implementing the no-cost and low-cost recommendations. To implement these measures, CBP can request a proposal to implement the measures from the operations contractor.

Installing solar domestic hot water heating or power generation systems are capital projects that require an engineering consultant to begin project development. In addition, the owner of the building will have to agree to installation of the solar systems if incentives or rebates from the state or the utility are used because they have multi-year operating requirements.

Recommended resources for CBP Houston Laboratory operations staff:

FEMP Retro-commissioning

http://www1.eere.energy.gov/femp/pdfs/om retrocx.pdf

FEMP Best Practices Operations and Maintenance http:///www1.eere.energy.gove/femp/operations maintenance/om bpguide.html

\subsection{Funding Assistance Available}

Federal energy projects can be funded or financed by various means. Energy projects can be funded with operation and maintenance funding if the resulting payback period is acceptable. If no appropriated funding is available, an alternative approach for Federal projects is to pursue financing energy services company (ESCO) via an energy savings performance contract (ESPC). EPSC contract methods enable a customer to finance the construction costs of the project with the savings that will take place after installation. 
The current electric utility provider Affordable Energy does not offer any utility rebate programs. State energy loans are available in Texas for Federal government projects but would not be applicable for leased buildings. There are no State of Texas renewable energy incentives for this project. 


\subsection{Assessment Team Members and Site Team}

The Redhorse ARRA assessment team for the audit included Jim Arends, PE, CEM, Energy Audit Team Technical Lead, and Hani Geeso, CEM, Energy Audit Team Member. Site support was provided by Randall Breaux, CBP Assistant Laboratory Director, and Bruce Chambers, Live Oak Gottesman Maintenance Engineer. William Sandusky, PNNL Program Manager, provided technical review of the report. 


\section{References}

American Society of Heating, Refrigerating, \& Air Conditioning Engineers (ASHRAE). 2007. ANSI/ASHRAE/IESNA Standard 90.1- 2007, Energy Standard for Buildings Except Low-Rise Residential Buildings. ASHRAE, Atlanta, Georgia.

E.H. Pechan \& Associates (Pechan). September 2008. The Emissions \& Generation Resource Integrated Database for 2007 (eGRID 2007). Report Number 08.09.006/9011.239. Springfield, Virginia.

eQUEST DOE-2 software was developed by James J. Hirsch \& Associates (JJH) in collaboration with Lawrence Berkeley National Laboratory (LBNL.). Can be accessed at http://doe2.com/equest/index.html

National Resources of Canada (NRC) 2010. RETScreen ${ }^{\circledR}$ Clean Energy Project Analysis Software from RETScreen International, Ottawa, Ontario, Canada. Can be accessed at http://www. retscreen.net/ang/t software.php 


\section{APPENDIX A}

\section{Model Output Files}





\section{Appendix A - Model Output Files}

\section{Baseline eQUEST Model Results}

\begin{tabular}{|c|c|c|c|c|c|c|c|c|c|c|c|c|c|}
\hline \multicolumn{14}{|c|}{ eQUEST Model Results Baseline Use } \\
\hline \multicolumn{14}{|c|}{ Electric Consumption ( $\mathrm{kWh} \times 000)$} \\
\hline & Jan & Feb & Mar & Apr & May & Jun & Jul & Aug & Sep & Oct & Nov & Dec & Total \\
\hline Space Cool & 14 & 8.5 & 16.6 & 26.9 & 37.1 & 48 & 56.5 & 53.1 & 42.7 & 30.4 & 19 & 11.5 & 364.20 \\
\hline Heat Reject. & 0 & 0 & 0 & 0 & 0 & 0 & 0 & 0 & 0 & 0 & 0 & 0 & 0 \\
\hline Refrigeration & 0 & 0 & 0 & 0 & 0 & 0 & 0 & 0 & 0 & 0 & 0 & 0 & 0 \\
\hline Space Heat & 0.1 & 0.1 & 0 & 0 & 0 & 0 & 0 & 0 & 0 & 0 & 0 & 0.1 & 0.5 \\
\hline HP Supp. & 0 & 0 & 0 & 0 & 0 & 0 & 0 & 0 & 0 & 0 & 0 & 0 & 0 \\
\hline Hot Water & 0 & 0 & 0 & 0 & 0 & 0 & 0 & 0 & 0 & 0 & 0 & 0 & 0 \\
\hline Vent. Fans & 6.6 & 5.3 & 5.2 & 5.3 & 5.6 & 6.1 & 6.5 & 6.3 & 6 & 5.6 & 5 & 5.8 & 69.2 \\
\hline Pumps \& Aux. & 2.6 & 2.2 & 2.7 & 3.1 & 3.6 & 3.9 & 4.2 & 4 & 3.7 & 3.3 & 2.8 & 2.5 & 38.5 \\
\hline Ext. Usage & 1.7 & 1.3 & 1.5 & 1.4 & 1.2 & 1.2 & 1.2 & 1.7 & 1.6 & 1.7 & 1.6 & 1.7 & 17.6 \\
\hline Misc. Equip. & 65.4 & 61.1 & 69.9 & 69.2 & 65.3 & 69.2 & 69.8 & 67.6 & 67 & 67.5 & 62.5 & 69.9 & 804.40 \\
\hline Task Lights & 0 & 0 & 0 & 0 & 0 & 0 & 0 & 0 & 0 & 0 & 0 & 0 & 0 \\
\hline Area Lights & 14.7 & 13.9 & 16 & 16 & 14.7 & 16 & 16 & 15.3 & 15.3 & 15.3 & 14 & 16 & 183.30 \\
\hline Total & 105 & 92.4 & 112 & 121.9 & 127.5 & 144.2 & 154.2 & 148.1 & 136.3 & 123.9 & 104.8 & 107.4 & $1,477.80$ \\
\hline \multirow[t]{3}{*}{ kWh } & 105,000 & 92,400 & 112,000 & 121,900 & 127,500 & 144,200 & 154,200 & 148,100 & 136,300 & 123,900 & 104,800 & 107,400 & $1,477,800$ \\
\hline & 131,136 & 105,216 & 85,056 & 123,072 & 101,376 & 184,896 & 184,896 & 160,896 & 145,536 & 120,960 & 62,592 & 40,896 & $1,446,528$ \\
\hline & $80 \%$ & $88 \%$ & $132 \%$ & $99 \%$ & $126 \%$ & $78 \%$ & $83 \%$ & $92 \%$ & $94 \%$ & $102 \%$ & $167 \%$ & $263 \%$ & $102 \%$ \\
\hline \multicolumn{14}{|c|}{ Gas Consumption (Btu x000,000,000) } \\
\hline & Jan & Feb & Mar & Apr & May & Jun & Jul & Aug & Sep & Oct & Nov & Dec & Total \\
\hline Space Cool & 0.14 & 0.09 & 0.16 & 0.23 & 0.34 & 0.38 & 0.44 & 0.42 & 0.35 & 0.27 & 0.18 & 0.12 & 3.13 \\
\hline Heat Reject. & 0 & 0 & 0 & 0 & 0 & 0 & 0 & 0 & 0 & 0 & 0 & 0 & 0 \\
\hline Refrigeration & 0 & 0 & 0 & 0 & 0 & 0 & 0 & 0 & 0 & 0 & 0 & 0 & 0 \\
\hline Space Heat & 0.23 & 0.17 & 0.06 & 0.02 & 0.02 & 0.01 & 0.01 & 0.01 & 0.01 & 0.02 & 0.05 & 0.16 & 0.78 \\
\hline HP Supp. & 0 & 0 & 0 & 0 & 0 & 0 & 0 & 0 & 0 & 0 & 0 & 0 & 0 \\
\hline Hot Water & 0 & 0 & 0 & 0 & 0 & 0 & 0 & 0 & 0 & 0 & 0 & 0 & 0.01 \\
\hline Vent. Fans & 0.07 & 0.06 & 0.05 & 0.05 & 0.05 & 0.05 & 0.05 & 0.05 & 0.05 & 0.05 & 0.05 & 0.06 & 0.64 \\
\hline Pumps \& Aux. & 0.03 & 0.02 & 0.03 & 0.03 & 0.04 & 0.03 & 0.04 & 0.04 & 0.03 & 0.03 & 0.03 & 0.03 & 0.38 \\
\hline Ext. Usage & 0.02 & 0.02 & 0.02 & 0.02 & 0.01 & 0.01 & 0.01 & 0.02 & 0.02 & 0.02 & 0.02 & 0.02 & 0.19 \\
\hline Misc. Equip. & 0.66 & 0.65 & 0.68 & 0.6 & 0.54 & 0.5 & 0.48 & 0.48 & 0.51 & 0.58 & 0.6 & 0.72 & 6.98 \\
\hline Task Lights & 0 & 0 & 0 & 0 & 0 & 0 & 0 & 0 & 0 & 0 & 0 & 0 & 0 \\
\hline Area Lights & 0.14 & 0.14 & 0.15 & 0.13 & 0.11 & 0.1 & 0.1 & 0.1 & 0.1 & 0.12 & 0.12 & 0.16 & 1.46 \\
\hline Total & 1.28 & 1.14 & 1.15 & 1.08 & 1.11 & 1.09 & 1.13 & 1.11 & 1.07 & 1.1 & 1.05 & 1.27 & 13.57 \\
\hline \multirow[t]{3}{*}{ Therms } & 12,800 & 11,400 & 11,500 & 10,800 & 11,100 & 10,900 & 11,300 & 11,100 & 10,700 & 11,000 & 10,500 & 12,700 & 135,700 \\
\hline & 7,740 & 9,330 & 8,780 & 12,320 & 11,340 & 11,340 & 11,474 & 11,474 & 12,200 & 11,040 & 19,440 & 13,740 & 140,218 \\
\hline & $165 \%$ & $122 \%$ & $131 \%$ & $88 \%$ & $98 \%$ & $96 \%$ & $98 \%$ & $97 \%$ & $88 \%$ & $100 \%$ & $54 \%$ & $92 \%$ & $97 \%$ \\
\hline
\end{tabular}




\section{AHU Optimum Start Model Results}

\begin{tabular}{|c|c|c|c|c|c|c|c|c|c|c|c|c|c|}
\hline \multicolumn{14}{|c|}{ eQUEST Model Results: Optimum Start } \\
\hline \multicolumn{14}{|c|}{ Electric Consumption ( $\mathrm{kWh} \times 000,000)$} \\
\hline & Jan & Feb & Mar & Apr & May & Jun & Jul & Aug & Sep & Oct & Nov & Dec & Total \\
\hline Space Cool & 13.8 & 8.4 & 16.4 & 26.6 & 36.9 & 47.7 & 56.2 & $\quad 52.8$ & 42.5 & 30.2 & 18.8 & 11.4 & 361.6 \\
\hline Heat Reject. & 0 & 0 & 0 & 0 & 0 & 0 & 0 & 0 & 0 & 0 & 0 & 0 & 0 \\
\hline Refrigeration & 0 & 0 & 0 & 0 & 0 & 0 & 0 & 0 & 0 & 0 & 0 & 0 & 0 \\
\hline Space Heat & 0.1 & 0.1 & 0 & 0 & 0 & 0 & 0 & 0 & 0 & 0 & 0 & 0.1 & 0.5 \\
\hline HP Supp. & 0 & 0 & 0 & 0 & 0 & 0 & 0 & 0 & 0 & 0 & 0 & 0 & 0 \\
\hline Hot Water & 0 & 0 & 0 & 0 & 0 & 0 & 0 & 0 & 0 & 0 & 0 & 0 & 0 \\
\hline Vent. Fans & 6.4 & 5.2 & 5.1 & 5.2 & 5.5 & 6.1 & 6.5 & 6.3 & 6 & 5.5 & 4.9 & 5.6 & 68.2 \\
\hline Pumps \& Aux. & 2.6 & 2.1 & 2.7 & 3.1 & 3.6 & 3.8 & 4.1 & 4 & 3.7 & 3.3 & 2.7 & 2.5 & 38.3 \\
\hline Ext. Usage & 1.7 & 1.3 & 1.5 & 1.4 & 1.2 & 1.2 & 1.2 & 1.7 & 1.6 & 1.7 & 1.6 & 1.7 & 17.6 \\
\hline Misc. Equip. & 65.4 & 61.1 & 69.9 & 69.2 & 65.3 & 69.2 & 69.8 & 67.6 & 67 & 67.5 & 62.5 & 69.9 & 804.40 \\
\hline Task Lights & 0 & 0 & 0 & 0 & 0 & 0 & 0 & 0 & 0 & 0 & 0 & 0 & 0 \\
\hline Area Lights & 14.7 & 13.9 & 16 & 16 & 14.7 & 16 & 16 & 15.3 & 15.3 & 15.3 & 14 & 16 & 183.3 \\
\hline Total & 104.7 & 92.2 & 111.5 & 121.5 & 127.3 & 143.9 & 153.9 & 147.8 & 136 & 123.6 & 104.5 & 107.1 & $1,473.90$ \\
\hline & & & & & & & & & & & & & \\
\hline & & & & & & & & & & & & & \\
\hline \multicolumn{14}{|c|}{ Gas Consumption (Btu x000,000) } \\
\hline & Jan & Feb & Mar & Apr & May & Jun & Jul & Aug & Sep & Oct & Nov & Dec & Total \\
\hline Space Cool & 0.13 & 0.09 & 0.16 & 0.23 & 0.34 & 0.38 & 0.44 & 0.42 & 0.35 & 0.27 & 0.18 & 0.12 & 3.11 \\
\hline Heat Reject. & 0 & 0 & 0 & 0 & 0 & 0 & 0 & 0 & 0 & 0 & 0 & 0 & 0 \\
\hline Refrigeration & 0 & 0 & 0 & 0 & 0 & 0 & 0 & 0 & 0 & 0 & 0 & 0 & 0 \\
\hline Space Heat & 0.22 & 0.16 & 0.06 & 0.02 & 0.02 & 0.01 & 0.01 & 0.01 & 0.01 & 0.02 & 0.04 & 0.15 & 0.73 \\
\hline HP Supp. & 0 & 0 & 0 & 0 & 0 & 0 & 0 & 0 & 0 & 0 & 0 & 0 & 0 \\
\hline Hot Water & 0 & 0 & 0 & 0 & 0 & 0 & 0 & 0 & 0 & 0 & 0 & 0 & 0.01 \\
\hline Vent. Fans & 0.07 & 0.06 & 0.05 & 0.05 & 0.05 & 0.05 & 0.05 & 0.05 & 0.05 & 0.05 & 0.05 & 0.06 & 0.63 \\
\hline Pumps \& Aux. & 0.03 & 0.02 & 0.03 & 0.03 & 0.04 & 0.03 & 0.04 & 0.04 & 0.03 & 0.03 & 0.03 & 0.03 & 0.38 \\
\hline Ext. Usage & 0.02 & 0.02 & 0.02 & 0.02 & 0.01 & 0.01 & 0.01 & 0.02 & 0.02 & 0.02 & 0.02 & 0.02 & 0.19 \\
\hline Misc. Equip. & 0.66 & 0.65 & 0.68 & 0.6 & 0.54 & 0.5 & 0.48 & 0.48 & 0.51 & 0.58 & 0.6 & 0.73 & 7 \\
\hline Task Lights & 0 & 0 & 0 & 0 & 0 & 0 & 0 & 0 & 0 & 0 & 0 & 0 & 0 \\
\hline Area Lights & 0.14 & 0.14 & 0.15 & 0.13 & 0.11 & 0.1 & 0.1 & 0.1 & 0.1 & 0.12 & 0.12 & 0.16 & 1.47 \\
\hline Total & 1.27 & 1.14 & 1.14 & 1.07 & 1.11 & 1.09 & 1.13 & 1.11 & 1.07 & 1.1 & 1.04 & 1.26 & 13.53 \\
\hline
\end{tabular}




\section{Holiday Schedule Model Results}

\begin{tabular}{|c|c|c|c|c|c|c|c|c|c|c|c|c|c|}
\hline \multicolumn{14}{|c|}{ eQUEST Model Results Holiday Scheduling } \\
\hline \multicolumn{14}{|c|}{ Electric Consumption (kWh x000,000) } \\
\hline & Jan & Feb & Mar & Apr & May & Jun & Jul & Aug & Sep & Oct & Nov & Dec & Total \\
\hline Space Cool & 13.9 & 8.5 & 16.6 & 26.9 & 37.1 & 48 & 56.4 & 53.1 & 42.6 & 30.3 & 18.8 & 11.5 & 363.60 \\
\hline Heat Reject. & 0 & 0 & 0 & 0 & 0 & 0 & 0 & 0 & 0 & 0 & 0 & 0 & 0 \\
\hline Refrigeration & 0 & 0 & 0 & 0 & 0 & 0 & 0 & 0 & 0 & 0 & 0 & 0 & 0 \\
\hline Space Heat & 0.1 & 0.1 & 0 & 0 & 0 & 0 & 0 & 0 & 0 & 0 & 0 & 0.1 & 0.5 \\
\hline HP Supp. & 0 & 0 & 0 & 0 & 0 & 0 & 0 & 0 & 0 & 0 & 0 & 0 & 0 \\
\hline Hot Water & 0 & 0 & 0 & 0 & 0 & 0 & 0 & 0 & 0 & 0 & 0 & 0 & 0 \\
\hline Vent. Fans & 6.5 & 5.3 & 5.2 & 5.3 & 5.5 & 6.1 & 6.5 & 6.3 & 6 & 5.6 & 5 & 5.7 & 69 \\
\hline Pumps \& Aux. & 2.6 & 2.2 & 2.7 & 3.1 & 3.6 & 3.9 & 4.2 & 4 & 3.7 & 3.3 & 2.8 & 2.5 & 38.5 \\
\hline Ext. Usage & 1.7 & 1.3 & 1.5 & 1.4 & 1.2 & 1.2 & 1.2 & 1.7 & 1.6 & 1.7 & 1.6 & 1.7 & 17.6 \\
\hline Misc. Equip. & 65.4 & 61.1 & 69.9 & 69.2 & 65.3 & 69.2 & 69.8 & 67.6 & 67 & 67.5 & 62.5 & 69.9 & 804.40 \\
\hline Task Lights & 0 & 0 & 0 & 0 & 0 & 0 & 0 & 0 & 0 & 0 & 0 & 0 & 0 \\
\hline Area Lights & 14.7 & 13.9 & 16 & 16 & 14.7 & 16 & 16 & 15.3 & 15.3 & 15.3 & 14 & 16 & 183.30 \\
\hline Total & 104.9 & 92.4 & 112 & 121.9 & 127.4 & 144.2 & 154 & 148.1 & 136.2 & 123.8 & 104.6 & 107.4 & $1,476.90$ \\
\hline \multicolumn{14}{|c|}{ Gas Consumption (Btu x000,000) } \\
\hline & Jan & Feb & Mar & Apr & May & Jun & Jul & Aug & Sep & Oct & Nov & Dec & Total \\
\hline Space Cool & 0.13 & 0.09 & 0.16 & 0.23 & 0.34 & 0.38 & 0.44 & 0.42 & 0.35 & 0.27 & 0.18 & 0.12 & 3.12 \\
\hline Heat Reject. & 0 & 0 & 0 & 0 & 0 & 0 & 0 & 0 & 0 & 0 & 0 & 0 & 0 \\
\hline Refrigeration & 0 & 0 & 0 & 0 & 0 & 0 & 0 & 0 & 0 & 0 & 0 & 0 & 0 \\
\hline Space Heat & 0.23 & 0.16 & 0.06 & 0.02 & 0.02 & 0.01 & 0.01 & 0.01 & 0.01 & 0.02 & 0.05 & 0.16 & 0.77 \\
\hline HP Supp. & 0 & 0 & 0 & 0 & 0 & 0 & 0 & 0 & 0 & 0 & 0 & 0 & 0 \\
\hline Hot Water & 0 & 0 & 0 & 0 & 0 & 0 & 0 & 0 & 0 & 0 & 0 & 0 & 0.01 \\
\hline Vent. Fans & 0.07 & 0.06 & 0.05 & 0.05 & 0.05 & 0.05 & 0.05 & 0.05 & 0.05 & 0.05 & 0.05 & 0.06 & 0.64 \\
\hline Pumps \& Aux. & 0.03 & 0.02 & 0.03 & 0.03 & 0.04 & 0.03 & 0.04 & 0.04 & 0.03 & 0.03 & 0.03 & 0.03 & 0.38 \\
\hline Ext. Usage & 0.02 & 0.02 & 0.02 & 0.02 & 0.01 & 0.01 & 0.01 & 0.02 & 0.02 & 0.02 & 0.02 & 0.02 & 0.19 \\
\hline Misc. Equip. & 0.66 & 0.65 & 0.68 & 0.6 & 0.54 & 0.5 & 0.48 & 0.48 & 0.51 & 0.58 & 0.6 & 0.72 & 6.98 \\
\hline Task Lights & 0 & 0 & 0 & 0 & 0 & 0 & 0 & 0 & 0 & 0 & 0 & 0 & 0 \\
\hline Area Lights & 0.14 & 0.14 & 0.15 & 0.13 & 0.11 & 0.1 & 0.1 & 0.1 & 0.1 & 0.12 & 0.12 & 0.16 & 1.46 \\
\hline Total & 1.28 & 1.14 & 1.15 & 1.08 & 1.11 & 1.09 & 1.13 & 1.11 & 1.07 & 1.1 & 1.04 & 1.27 & 13.56 \\
\hline
\end{tabular}




\section{Supply Air Reset Model Results}

\begin{tabular}{|c|c|c|c|c|c|c|c|c|c|c|c|c|c|}
\hline \multicolumn{14}{|c|}{ eQUEST Model Results Supply Air Reset } \\
\hline \multicolumn{14}{|c|}{ Electric Consumption (kWh x000,000) } \\
\hline & Jan & Feb & Mar & Apr & May & Jun & Jul & Aug & Sep & Oct & Nov & Dec & Total \\
\hline Space Cool & 11.5 & 6.2 & $\quad 13.3$ & 23.7 & 33.3 & 45.6 & 54.4 & 50.5 & 40.1 & 26.3 & $\quad 15.7$ & 8.8 & 329.4 \\
\hline Heat Reject. & 0 & 0 & 0 & 0 & 0 & 0 & 0 & 0 & 0 & 0 & 0 & 0 & 0 \\
\hline Refrigeration & 0 & 0 & 0 & 0 & 0 & 0 & 0 & 0 & 0 & 0 & 0 & 0 & 0 \\
\hline Space Heat & 0.1 & 0.1 & 0 & 0 & 0 & 0 & 0 & 0 & 0 & 0 & 0 & 0.1 & 0.3 \\
\hline HP Supp. & 0 & 0 & 0 & 0 & 0 & 0 & 0 & 0 & 0 & 0 & 0 & 0 & 0 \\
\hline Hot Water & 0 & 0 & 0 & 0 & 0 & 0 & 0 & 0 & 0 & 0 & 0 & 0 & 0 \\
\hline Vent. Fans & 6.8 & 5.6 & 5.7 & 6 & 6.3 & 6.8 & 7.2 & 7 & 6.8 & 6.4 & 5.6 & 6 & 76.3 \\
\hline Pumps \& Aux. & 2.4 & 2 & 2.4 & 2.8 & 3.1 & 3.5 & 3.8 & 3.6 & 3.3 & 2.9 & 2.5 & 2.3 & 34.6 \\
\hline Ext. Usage & 1.7 & 1.3 & 1.5 & 1.4 & 1.2 & 1.2 & 1.2 & 1.7 & 1.6 & 1.7 & 1.6 & 1.7 & 17.6 \\
\hline Misc. Equip. & 65.4 & 61.1 & 69.9 & 69.2 & 65.3 & 69.2 & 69.8 & 67.6 & 67 & 67.5 & 62.5 & 69.9 & 804.40 \\
\hline Task Lights & 0 & 0 & 0 & 0 & 0 & 0 & 0 & 0 & 0 & 0 & 0 & 0 & 0 \\
\hline Area Lights & 14.7 & 13.9 & 16 & 16 & 14.7 & 16 & 16 & 15.3 & 15.3 & 15.3 & 14 & 16 & 183.3 \\
\hline Total & 102.6 & 90.2 & 108.9 & 119 & 124 & 142.2 & 152.4 & 145.8 & 134.1 & 120.2 & 101.8 & 104.8 & $1,445.90$ \\
\hline & & & & & & & & & & & & & \\
\hline \multirow{2}{*}{\multicolumn{14}{|c|}{ Gas Consumption (Btu x000,000,000) }} \\
\hline & & & & & & & & & & & & & \\
\hline & Jan & Feb & Mar & Apr & May & Jun & Jul & Aug & Sep & Oct & Nov & Dec & Total \\
\hline Space Cool & 0.11 & 0.06 & 0.12 & 0.19 & 0.29 & 0.35 & 0.42 & 0.39 & 0.31 & 0.22 & $\quad 0.14$ & 0.08 & 2.68 \\
\hline Heat Reject. & 0 & 0 & 0 & 0 & 0 & 0 & 0 & 0 & 0 & 0 & 0 & 0 & 0 \\
\hline Refrigeration & 0 & 0 & 0 & 0 & 0 & 0 & 0 & 0 & 0 & 0 & 0 & 0 & 0 \\
\hline Space Heat & 0.2 & 0.13 & 0.03 & 0 & 0 & 0 & 0 & 0 & 0 & 0 & 0.02 & 0.12 & 0.50 \\
\hline HP Supp. & 0 & 0 & 0 & 0 & 0 & 0 & 0 & 0 & 0 & 0 & 0 & 0 & 0 \\
\hline Hot Water & 0 & 0 & 0 & 0 & 0 & 0 & 0 & 0 & 0 & 0 & 0 & 0 & 0.01 \\
\hline Vent. Fans & 0.08 & 0.06 & 0.06 & 0.05 & 0.06 & 0.05 & 0.05 & 0.05 & 0.05 & 0.06 & 0.06 & 0.07 & 0.7 \\
\hline Pumps \& Aux. & 0.03 & 0.02 & 0.03 & 0.03 & 0.03 & 0.03 & 0.03 & 0.03 & 0.03 & 0.03 & 0.03 & 0.03 & 0.33 \\
\hline Ext. Usage & 0.02 & 0.02 & 0.02 & 0.02 & 0.01 & 0.01 & 0.01 & 0.02 & 0.02 & 0.02 & 0.02 & 0.02 & 0.2 \\
\hline Misc. Equip. & 0.66 & 0.65 & 0.68 & 0.6 & 0.54 & 0.5 & 0.49 & 0.48 & 0.5 & 0.58 & 0.6 & 0.73 & 7.02 \\
\hline Task Lights & 0 & 0 & 0 & 0 & 0 & 0 & 0 & 0 & 0 & 0 & 0 & 0 & 0 \\
\hline Area Lights & 0.14 & 0.14 & 0.15 & 0.13 & 0.11 & 0.1 & 0.1 & 0.1 & 0.1 & 0.12 & 0.12 & 0.16 & 1.47 \\
\hline Total & 1.23 & 1.09 & 1.08 & 1.02 & 1.03 & 1.05 & 1.1 & 1.07 & 1.02 & 1.03 & 0.99 & 1.21 & 12.91 \\
\hline
\end{tabular}




\section{Static Pressure Reset Model Results}

\begin{tabular}{|c|c|c|c|c|c|c|c|c|c|c|c|c|c|}
\hline \multicolumn{14}{|c|}{ eQUEST Model Results: Static Pressure Reset } \\
\hline \multicolumn{14}{|c|}{ Electric Consumption $(\mathrm{kWh} \times 000,000)$} \\
\hline & Jan & Feb & Mar & Apr & May & Jun & Jul & Aug & Sep & Oct & Nov & Dec & Total \\
\hline Space Cool & 14 & 8.5 & 16.4 & 26.7 & 36.9 & 47.8 & 56.4 & 52.9 & 42.6 & 30.1 & 18.8 & 11.5 & 362.6 \\
\hline Heat Reject. & 0 & 0 & 0 & 0 & 0 & 0 & 0 & 0 & 0 & 0 & 0 & 0 & 0 \\
\hline Refrigeration & 0 & 0 & 0 & 0 & 0 & 0 & 0 & 0 & 0 & 0 & 0 & 0 & 0 \\
\hline Space Heat & 0.1 & 0.1 & 0 & 0 & 0 & 0 & 0 & 0 & 0 & 0 & 0 & 0.1 & 0.5 \\
\hline HP Supp. & 0 & 0 & 0 & 0 & 0 & 0 & 0 & 0 & 0 & 0 & 0 & 0 & 0 \\
\hline Hot Water & 0 & 0 & 0 & 0 & 0 & 0 & 0 & 0 & 0 & 0 & 0 & 0 & 0 \\
\hline Vent. Fans & 5.7 & 4.5 & 4.3 & 4.6 & 4.8 & 5.7 & 6.1 & 5.9 & 5.5 & 4.8 & 4 & 4.8 & 60.9 \\
\hline Pumps \& Aux. & 2.6 & 2.1 & 2.7 & 3.1 & 3.6 & 3.8 & 4.2 & 4 & 3.7 & 3.3 & 2.7 & 2.5 & 38.3 \\
\hline Ext. Usage & 1.7 & 1.3 & 1.5 & 1.4 & 1.2 & 1.2 & 1.2 & 1.7 & 1.6 & 1.7 & 1.6 & 1.7 & 17.6 \\
\hline Misc. Equip. & 65.4 & 61.1 & 69.9 & 69.2 & 65.3 & 69.2 & 69.8 & 67.6 & 67 & 67.5 & 62.5 & 69.9 & 804.40 \\
\hline Task Lights & 0 & 0 & 0 & 0 & 0 & 0 & 0 & 0 & 0 & 0 & 0 & 0 & 0 \\
\hline Area Lights & 14.7 & 13.9 & 16 & 16 & 14.7 & 16 & 16 & 15.3 & 15.3 & 15.3 & 14 & 16 & 183.3 \\
\hline Total & 104.2 & 91.6 & 110.8 & 121 & 126.6 & 143.7 & 153.7 & 147.5 & 135.6 & 122.9 & 103.7 & 106.4 & $1,467.70$ \\
\hline
\end{tabular}

Gas Consumption (Btu $\times 000,000$ )

\begin{tabular}{|c|c|c|c|c|c|c|c|c|c|c|c|c|c|}
\hline & Jan & Feb & Mar & Apr & May & Jun & Jul & Aug & Sep & Oct & Nov & Dec & Total \\
\hline Space Cool & 0.14 & 0.09 & 0.16 & 0.23 & 0.34 & 0.38 & 0.44 & 0.42 & 0.35 & 0.27 & 0.18 & 0.12 & 3.11 \\
\hline Heat Reject. & 0 & 0 & 0 & 0 & 0 & 0 & 0 & 0 & 0 & 0 & 0 & 0 & 0 \\
\hline Refrigeration & 0 & 0 & 0 & 0 & 0 & 0 & 0 & 0 & 0 & 0 & 0 & 0 & 0 \\
\hline Space Heat & 0.23 & 0.18 & 0.07 & 0.02 & 0.02 & 0.01 & 0.01 & 0.01 & 0.01 & 0.02 & 0.05 & 0.16 & 0.80 \\
\hline HP Supp. & 0 & 0 & 0 & 0 & 0 & 0 & 0 & 0 & 0 & 0 & 0 & 0 & 0 \\
\hline Hot Water & 0 & 0 & 0 & 0 & 0 & 0 & 0 & 0 & 0 & 0 & 0 & 0 & 0.01 \\
\hline Vent. Fans & 0.06 & 0.05 & 0.04 & 0.04 & 0.04 & 0.04 & 0.04 & 0.04 & 0.04 & 0.04 & 0.04 & 0.05 & 0.54 \\
\hline Pumps \& Aux. & 0.03 & 0.02 & 0.03 & 0.03 & 0.04 & 0.03 & 0.04 & 0.04 & 0.03 & 0.03 & 0.03 & 0.03 & 0.38 \\
\hline Ext. Usage & 0.02 & 0.02 & 0.02 & 0.02 & 0.01 & 0.01 & 0.01 & 0.02 & 0.02 & 0.02 & 0.02 & 0.02 & 0.19 \\
\hline Misc. Equip. & 0.66 & 0.65 & 0.68 & 0.6 & 0.54 & 0.5 & 0.48 & 0.48 & 0.51 & 0.58 & 0.6 & 0.73 & 7.01 \\
\hline Task Lights & 0 & 0 & 0 & 0 & 0 & 0 & 0 & 0 & 0 & 0 & 0 & 0 & 0 \\
\hline Area Lights & 0.14 & 0.14 & 0.15 & 0.13 & 0.11 & 0.1 & 0.1 & 0.1 & 0.1 & 0.12 & 0.12 & 0.16 & 1.47 \\
\hline Total & 1.28 & 1.15 & 1.14 & 1.07 & 1.1 & 1.08 & 1.13 & 1.1 & 1.06 & 1.09 & 1.04 & 1.27 & 13.51 \\
\hline
\end{tabular}




\section{Chilled Water Temperature Reset Model Result}

\begin{tabular}{|c|c|c|c|c|c|c|c|c|c|c|c|c|c|}
\hline \multicolumn{14}{|c|}{ eQUEST Model Results: Chilled Water Reset } \\
\hline \multicolumn{14}{|c|}{ Electric Consumption (kWh x000,000) } \\
\hline & Jan & Feb & Mar & Apr & May & Jun & Jul & Aug & Sep & Oct & Nov & Dec & Total \\
\hline Space Cool & 13.1 & 7.7 & 15.6 & 25.9 & 35.8 & 46.4 & 54.5 & 51.3 & 41.5 & 29.3 & 18 & 10.6 & 349.7 \\
\hline Heat Reject. & 0 & 0 & 0 & 0 & 0 & 0 & 0 & 0 & 0 & 0 & 0 & 0 & 0 \\
\hline Refrigeration & 0 & 0 & 0 & 0 & 0 & 0 & 0 & 0 & 0 & 0 & 0 & 0 & 0 \\
\hline Space Heat & 0.1 & 0.1 & 0 & 0 & 0 & 0 & 0 & 0 & 0 & 0 & 0 & 0.1 & 0.5 \\
\hline HP Supp. & 0 & 0 & 0 & 0 & 0 & 0 & 0 & 0 & 0 & 0 & 0 & 0 & 0 \\
\hline Hot Water & 0 & 0 & 0 & 0 & 0 & 0 & 0 & 0 & 0 & 0 & 0 & 0 & 0 \\
\hline Vent. Fans & 6.6 & 5.3 & 5.2 & 5.3 & 5.6 & 6.1 & 6.5 & 6.3 & 6 & 5.6 & 5 & 5.8 & 69.2 \\
\hline Pumps \& Aux. & 3 & 2.4 & 3.2 & 3.6 & 4 & 4.1 & 4.3 & 4.2 & 3.9 & 3.8 & 3.2 & 2.8 & 42.3 \\
\hline Ext. Usage & 1.7 & 1.3 & 1.5 & 1.4 & 1.2 & 1.2 & 1.2 & 1.7 & 1.6 & 1.7 & 1.6 & 1.7 & 17.6 \\
\hline Misc. Equip. & 65.4 & 61.1 & 69.9 & 69.2 & 65.3 & 69.2 & 69.8 & 67.6 & 67 & 67.5 & 62.5 & 69.9 & 804.40 \\
\hline Task Lights & 0 & 0 & 0 & 0 & 0 & 0 & 0 & 0 & 0 & 0 & 0 & 0 & 0 \\
\hline Area Lights & 14.7 & 13.9 & 16 & 16 & 14.7 & 16 & 16 & 15.3 & 15.3 & 15.3 & 14 & 16 & 183.3 \\
\hline Total & 104.5 & 91.9 & 111.5 & 121.4 & 126.6 & 142.8 & 152.2 & 146.4 & 135.3 & 123.3 & 104.3 & 106.8 & $1,467.00$ \\
\hline \multicolumn{14}{|c|}{ Gas Consumption (Btu x000,000,000) } \\
\hline & Jan & Feb & Mar & Apr & May & Jun & Jul & Aug & Sep & Oct & Nov & Dec & Total \\
\hline Space Cool & 0.13 & 0.08 & 0.15 & 0.23 & 0.33 & 0.37 & 0.43 & 0.41 & 0.34 & 0.26 & 0.17 & 0.11 & 3 \\
\hline Heat Reject. & 0 & 0 & 0 & 0 & 0 & 0 & 0 & 0 & 0 & 0 & 0 & 0 & 0 \\
\hline Refrigeration & 0 & 0 & 0 & 0 & 0 & 0 & 0 & 0 & 0 & 0 & 0 & 0 & 0 \\
\hline Space Heat & 0.23 & 0.17 & 0.06 & 0.02 & 0.02 & 0.01 & 0.01 & 0.01 & 0.01 & 0.02 & 0.05 & 0.16 & 0.78 \\
\hline HP Supp. & 0 & 0 & 0 & 0 & 0 & 0 & 0 & 0 & 0 & 0 & 0 & 0 & 0 \\
\hline Hot Water & 0 & 0 & 0 & 0 & 0 & 0 & 0 & 0 & 0 & 0 & 0 & 0 & 0.01 \\
\hline Vent. Fans & 0.07 & 0.06 & 0.05 & 0.05 & 0.05 & 0.05 & 0.05 & 0.05 & 0.05 & 0.05 & 0.05 & 0.06 & 0.65 \\
\hline Pumps \& Aux. & 0.03 & 0.03 & 0.03 & 0.03 & 0.04 & 0.04 & 0.04 & 0.04 & 0.04 & 0.04 & 0.03 & 0.03 & 0.42 \\
\hline Ext. Usage & 0.02 & 0.02 & 0.02 & 0.02 & 0.01 & 0.01 & 0.01 & 0.02 & 0.02 & 0.02 & 0.02 & 0.02 & 0.19 \\
\hline Misc. Equip. & 0.66 & 0.65 & 0.68 & 0.6 & 0.54 & 0.5 & 0.49 & 0.48 & 0.51 & 0.58 & 0.6 & 0.73 & 7.02 \\
\hline Task Lights & 0 & 0 & 0 & 0 & 0 & 0 & 0 & 0 & 0 & 0 & 0 & 0 & 0 \\
\hline Area Lights & 0.14 & 0.14 & 0.15 & 0.13 & 0.11 & 0.11 & 0.1 & 0.1 & 0.1 & 0.12 & 0.12 & 0.16 & 1.47 \\
\hline Total & 1.28 & 1.14 & 1.15 & 1.08 & 1.11 & 1.08 & 1.13 & 1.1 & 1.07 & 1.1 & 1.05 & 1.27 & 13.54 \\
\hline
\end{tabular}




\section{Boiler Heating Water Reset Model Results}

\begin{tabular}{|c|c|c|c|c|c|c|c|c|c|c|c|c|c|}
\hline \multicolumn{14}{|c|}{ eQUEST Model Results: Heating Water Reset } \\
\hline \multicolumn{14}{|c|}{ Electric Consumption (kWh x000,000) } \\
\hline & Jan & Feb & Mar & Apr & May & Jun & Jul & Aug & Sep & Oct & Nov & Dec & Total \\
\hline Space Cool & 14 & 8.5 & 16.6 & 26.9 & 37.1 & 48 & 56.5 & 53.1 & 42.7 & 30.4 & 19 & 11.5 & 364.2 \\
\hline Heat Reject. & 0 & 0 & 0 & 0 & 0 & 0 & 0 & 0 & 0 & 0 & 0 & 0 & 0 \\
\hline Refrigeration & 0 & 0 & 0 & 0 & 0 & 0 & 0 & 0 & 0 & 0 & 0 & 0 & 0 \\
\hline Space Heat & 0.1 & 0.1 & 0 & 0 & 0 & 0 & 0 & 0 & 0 & 0 & 0 & 0.1 & 0.5 \\
\hline HP Supp. & 0 & 0 & 0 & 0 & 0 & 0 & 0 & 0 & 0 & 0 & 0 & 0 & 0 \\
\hline Hot Water & 0 & 0 & 0 & 0 & 0 & 0 & 0 & 0 & 0 & 0 & 0 & 0 & 0 \\
\hline Vent. Fans & 6.6 & 5.3 & 5.2 & 5.3 & 5.6 & 6.1 & 6.5 & 6.3 & 6 & 5.6 & 5 & 5.8 & 69.2 \\
\hline Pumps \& Aux. & 2.7 & 2.2 & 2.7 & 3.1 & 3.6 & 3.9 & 4.2 & 4 & 3.7 & 3.4 & 2.8 & 2.5 & 38.7 \\
\hline Ext. Usage & 1.7 & 1.3 & 1.5 & 1.4 & 1.2 & 1.2 & 1.2 & 1.7 & 1.6 & 1.7 & 1.6 & 1.7 & 17.6 \\
\hline Misc. Equip. & 65.4 & 61.1 & 69.9 & 69.2 & 65.3 & 69.2 & 69.8 & 67.6 & 67 & 67.5 & 62.5 & 69.9 & 804.40 \\
\hline Task Lights & 0 & 0 & 0 & 0 & 0 & 0 & 0 & 0 & 0 & 0 & 0 & 0 & 0 \\
\hline Area Lights & 14.7 & 13.9 & 16 & 16 & 14.7 & 16 & 16 & 15.3 & 15.3 & 15.3 & 14 & 16 & 183.3 \\
\hline Total & 105.1 & 92.5 & 112 & 121.9 & 127.6 & 144.2 & 154.2 & 148.1 & 136.3 & 123.9 & 104.9 & 107.5 & $1,478.00$ \\
\hline \multicolumn{14}{|c|}{ Gas Consumption (Btu x000,000,000) } \\
\hline & Jan & Feb & Mar & Apr & May & Jun & Jul & Aug & Sep & Oct & Nov & Dec & Total \\
\hline Space Cool & 0.14 & 0.09 & 0.16 & 0.23 & 0.34 & 0.38 & 0.44 & 0.42 & 0.35 & 0.27 & 0.18 & 0.12 & 3.13 \\
\hline Heat Reject. & 0 & 0 & 0 & 0 & 0 & 0 & 0 & 0 & 0 & 0 & 0 & 0 & 0 \\
\hline Refrigeration & 0 & 0 & 0 & 0 & 0 & 0 & 0 & 0 & 0 & 0 & 0 & 0 & 0 \\
\hline Space Heat & 0.23 & 0.17 & 0.06 & 0.02 & 0.02 & 0.01 & 0.01 & 0.01 & 0.01 & 0.02 & 0.05 & 0.16 & 0.78 \\
\hline HP Supp. & 0 & 0 & 0 & 0 & 0 & 0 & 0 & 0 & 0 & 0 & 0 & 0 & 0 \\
\hline Hot Water & 0 & 0 & 0 & 0 & 0 & 0 & 0 & 0 & 0 & 0 & 0 & 0 & 0.01 \\
\hline Vent. Fans & 0.07 & 0.06 & 0.05 & 0.05 & 0.05 & 0.05 & 0.05 & 0.05 & 0.05 & 0.05 & 0.05 & 0.06 & 0.64 \\
\hline Pumps \& Aux. & 0.03 & 0.03 & 0.03 & 0.03 & 0.04 & 0.03 & 0.04 & 0.04 & 0.03 & 0.03 & 0.03 & 0.03 & 0.38 \\
\hline Ext. Usage & 0.02 & 0.02 & 0.02 & 0.02 & 0.01 & 0.01 & 0.01 & 0.02 & 0.02 & 0.02 & 0.02 & 0.02 & 0.19 \\
\hline Misc. Equip. & 0.66 & 0.65 & 0.68 & 0.6 & 0.54 & 0.5 & 0.48 & 0.48 & 0.51 & 0.58 & 0.6 & 0.72 & 6.98 \\
\hline Task Lights & 0 & 0 & 0 & 0 & 0 & 0 & 0 & 0 & 0 & 0 & 0 & 0 & 0 \\
\hline Area Lights & 0.14 & 0.14 & 0.15 & 0.13 & 0.11 & 0.1 & 0.1 & 0.1 & 0.1 & 0.12 & 0.12 & 0.16 & 1.46 \\
\hline Total & 1.28 & 1.14 & 1.15 & 1.08 & 1.11 & 1.09 & 1.13 & 1.11 & 1.07 & 1.1 & 1.05 & 1.27 & 13.58 \\
\hline
\end{tabular}




\section{No Touch Faucets Model Results}

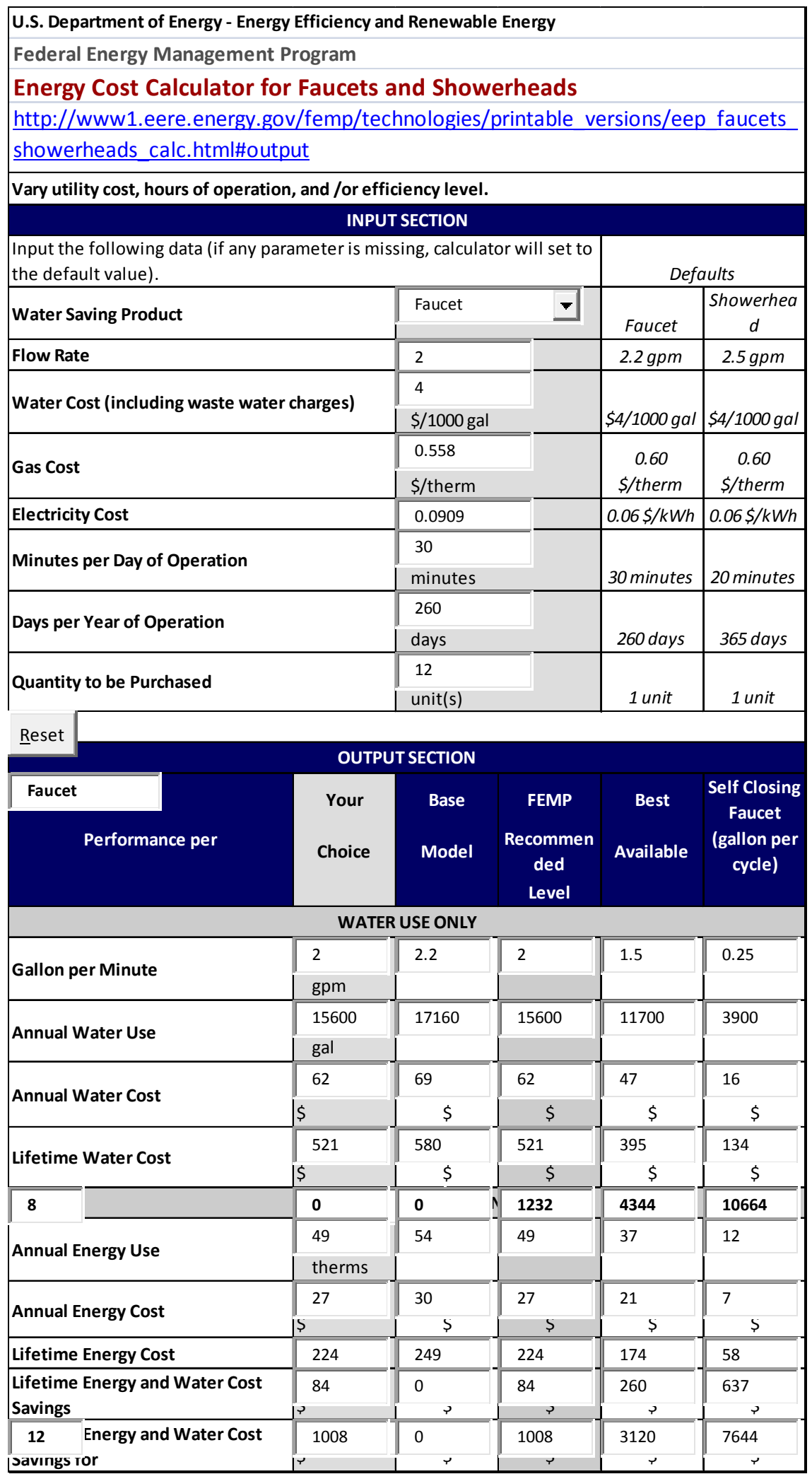




\section{No Touch Urinals Model Results}

\begin{tabular}{|c|c|c|c|c|}
\hline \multicolumn{5}{|c|}{ U.S. Department of Energy - Energy Efficiency and Renewable Energy } \\
\hline \multicolumn{5}{|c|}{ Federal Energy Management Program } \\
\hline \multicolumn{5}{|c|}{ Energy Cost Calculator for Urinals } \\
\hline \multirow{2}{*}{\multicolumn{5}{|c|}{$\begin{array}{l}\text { http://www1.eere.energy.gov/femp/technologies/printable versions/eep to } \\
\text { ilets urinals calc.html\#output }\end{array}$}} \\
\hline & & & & \\
\hline \multicolumn{5}{|c|}{ Vary water cost, frequency of operation, and /or efficiency level. } \\
\hline \multicolumn{5}{|c|}{ INPUT SECTION } \\
\hline \multicolumn{5}{|c|}{$\begin{array}{l}\text { This calculator assumes that early replacement of a urinal or toilet will take place with } 10 \\
\text { years of life remaining for existing fixture. }\end{array}$} \\
\hline \multicolumn{3}{|c|}{$\begin{array}{l}\text { Input the following data (if any parameter is missing, calculator } \\
\text { will set to default value). }\end{array}$} & \multicolumn{2}{|c|}{ Defaults } \\
\hline Water Saving Product & Urinal & $\nabla$ & \multicolumn{2}{|c|}{ Urinal } \\
\hline \multirow{2}{*}{ Gallons per Flush } & .5 & & \multirow{2}{*}{\multicolumn{2}{|c|}{$1.0 \mathrm{gpf}$}} \\
\hline & gpf & & & \\
\hline Quantity to be Purchased & 3 & & \multicolumn{2}{|c|}{1} \\
\hline \multirow{2}{*}{$\begin{array}{l}\text { Water Cost (including waste water } \\
\text { charges) }\end{array}$} & 4 & & \multirow{2}{*}{\multicolumn{2}{|c|}{$\$ 4 / 1000 \mathrm{gal}$}} \\
\hline & $\$ / 1000$ gal & & & \\
\hline \multirow{2}{*}{ Flushes per Day } & 30 & & \multirow{2}{*}{\multicolumn{2}{|c|}{30 flushes }} \\
\hline & flushes & & & \\
\hline \multirow{2}{*}{ Days per Year } & 260 & & \multirow{2}{*}{\multicolumn{2}{|c|}{260 days }} \\
\hline & days & & & \\
\hline \multicolumn{5}{|l|}{$\underline{\text { Reset }}$} \\
\hline \multicolumn{5}{|c|}{ OUTPUT SECTION } \\
\hline \multirow{2}{*}{ Performance per } & Your & Typical & \multirow{2}{*}{$\begin{array}{l}\text { Recommen } \\
\text { ded Level } \\
\text { (New Unit) }\end{array}$} & \multirow{2}{*}{ Best } \\
\hline & Choice & $\begin{array}{l}\text { Existing } \\
\text { Unit }\end{array}$ & & \\
\hline \multirow{2}{*}{ Gallon per Flush } & .5 & 3 & 1 & 0 \\
\hline & gpf & & & \\
\hline \multirow{2}{*}{ Annual Water Use } & 3900 & 23400 & 7800 & 0 \\
\hline & gal & & & \\
\hline
\end{tabular}




\section{No Touch Toilets Model Results}

\begin{tabular}{|c|c|c|c|c|}
\hline Toilet Water Use & & & & \\
\hline Number of toilets & & 9 & & \\
\hline Number of people & & 30 & & \\
\hline Flushes/person/day & & 2 & \multicolumn{2}{|c|}{ Use 5 for residential, 2 for office use } \\
\hline Days used per week & & 7 & \multicolumn{2}{|c|}{7 for residential, 5 for office } \\
\hline Existing single flush volume (US gal) & & 1.6 & \multicolumn{2}{|c|}{ Generally $5,3.5$ or 1.6 gal/flush } \\
\hline Water Consumption Calculations & & & & \\
\hline & & $\begin{array}{l}\text { Single } \\
\text { Flush } \\
\text { Toilets }\end{array}$ & $\begin{array}{c}\text { No } \\
\text { Touch } \\
\text { Toilets }\end{array}$ & \\
\hline Flush Volume & gal & 1.6 & 1.28 & \\
\hline Flushes per day & $\#$ & 60 & 60 & \\
\hline Water use per day & gal & 96 & 76.8 & \\
\hline Water use per toilet per day & gal & 10.7 & 8.5 & \\
\hline Water use per year & gal & 34944 & 27955 & \\
\hline Daily water use reduction & & & 19.2 & gal/day \\
\hline Annual Water use reduction & & & 6989 & gal/yr \\
\hline
\end{tabular}


Solar Domestic Hot Water Model Results

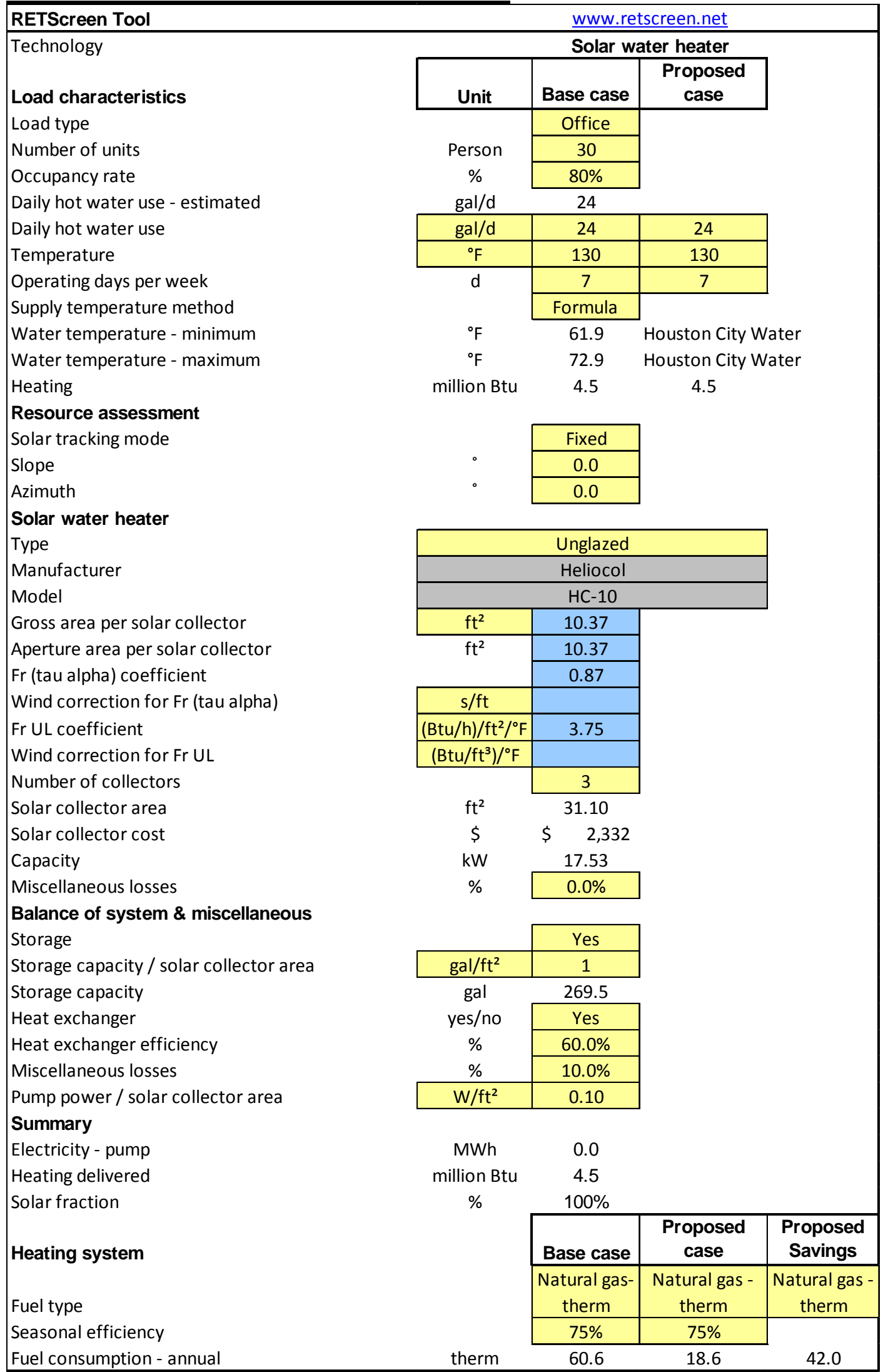


Solar Power Generation Model Results

\begin{tabular}{|c|c|c|c|c|c|}
\hline \multicolumn{6}{|c|}{ PV Watts AC Energy \& Cost Savings } \\
\hline \multicolumn{2}{|c|}{ Station Identification } & \multicolumn{4}{|c|}{ Results } \\
\hline \multicolumn{2}{|c|}{ Station Identification } & \multirow[t]{2}{*}{ Month } & Solar Radiation & AC Energy & $\begin{array}{c}\text { Energy } \\
\text { Value }\end{array}$ \\
\hline City: & Houston & & $\left(\mathrm{kWh} / \mathrm{m}^{2} /\right.$ day $)$ & $(\mathrm{kWh})$ & $(\$)$ \\
\hline State: & Texas & 1 & 3.68 & 5871 & 533.67 \\
\hline Latitude: & $29.98^{\circ} \mathrm{N}$ & 2 & 4.12 & 5853 & 532.04 \\
\hline Longitude: & $95.37^{\circ} \mathrm{W}$ & 3 & 4.82 & 7484 & 680.30 \\
\hline Elevation: & $33 \mathrm{~m}$ & 4 & 4.98 & 7342 & 667.39 \\
\hline \multicolumn{2}{|c|}{ PV System Specifications } & 5 & 5.24 & 7813 & 710.20 \\
\hline DC Rating: & $70.0 \mathrm{~kW}$ & 6 & 5.53 & 7854 & 713.93 \\
\hline DC to AC Derate Factor: & $\begin{array}{r}0.77 \\
\end{array}$ & 7 & 5.43 & 7895 & 717.66 \\
\hline AC Rating: & $53.9 \mathrm{~kW}$ & 8 & 5.44 & 7989 & 726.20 \\
\hline Array Type: & Fixed Tilt & 9 & 5.40 & 7747 & 704.20 \\
\hline Array Tilt: & $30.0^{\circ}$ & 10 & 5.19 & 7785 & 707.66 \\
\hline Array Azimuth: & $180.0^{\circ}$ & 11 & 4.33 & 6475 & 588.58 \\
\hline \multicolumn{2}{|l|}{ Energy Specifications } & 12 & 3.34 & 5280 & 479.95 \\
\hline \multirow[t]{3}{*}{ Cost of Electricity: } & $9.1 \mathrm{c} / \mathrm{kWh}$ & & & & \\
\hline & & Year & 4.79 & 85387 & 7761.68 \\
\hline & & & & & \\
\hline
\end{tabular}




\section{APPENDIX B}

\section{Photographs}





\section{Appendix B - Photographs}

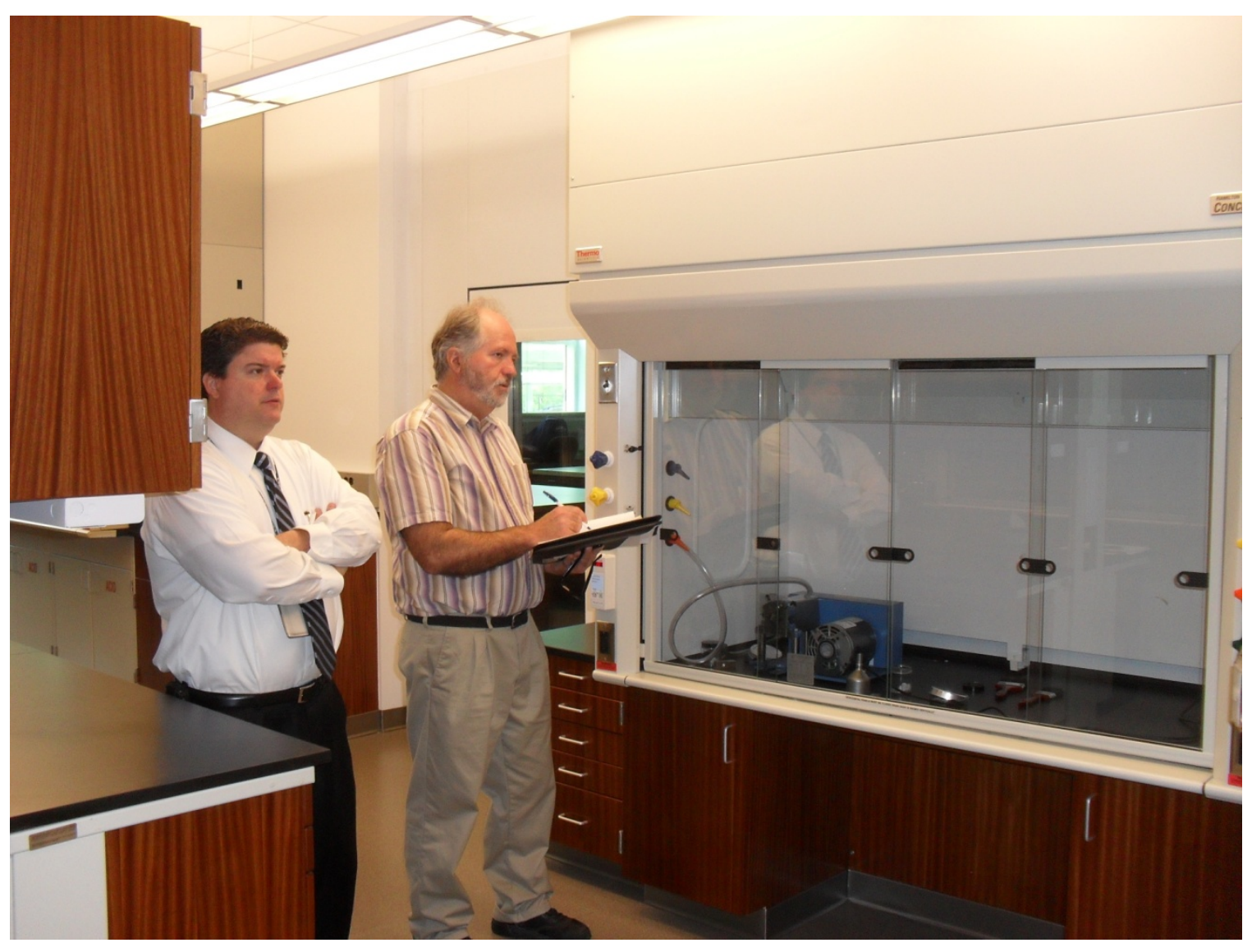

Photo 2: Randall Breaux, CBP, and Jim Arends, PE, CEM, Redhorse, inspecting laboratory fume hood during FEMP energy audit site visit, April 2010. 


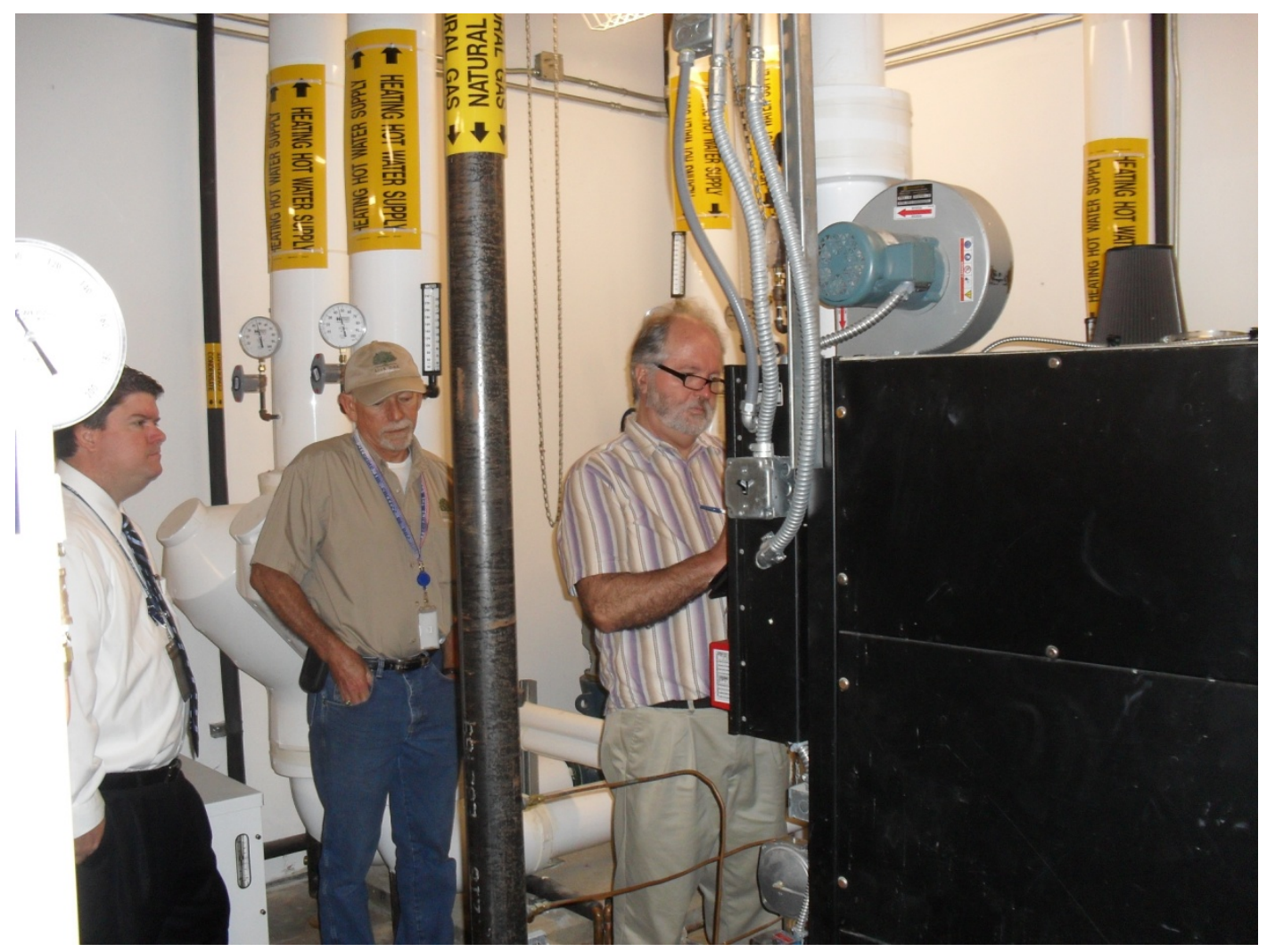

Photo 3: Randall Breaux CBP, Bruce Chambers, Live Oak Gottesman, and Jim Arends PE, CEM, Redhorse Corporation, inspecting backup hot water boiler unit during FEMP energy audit site visit, April 2010. 


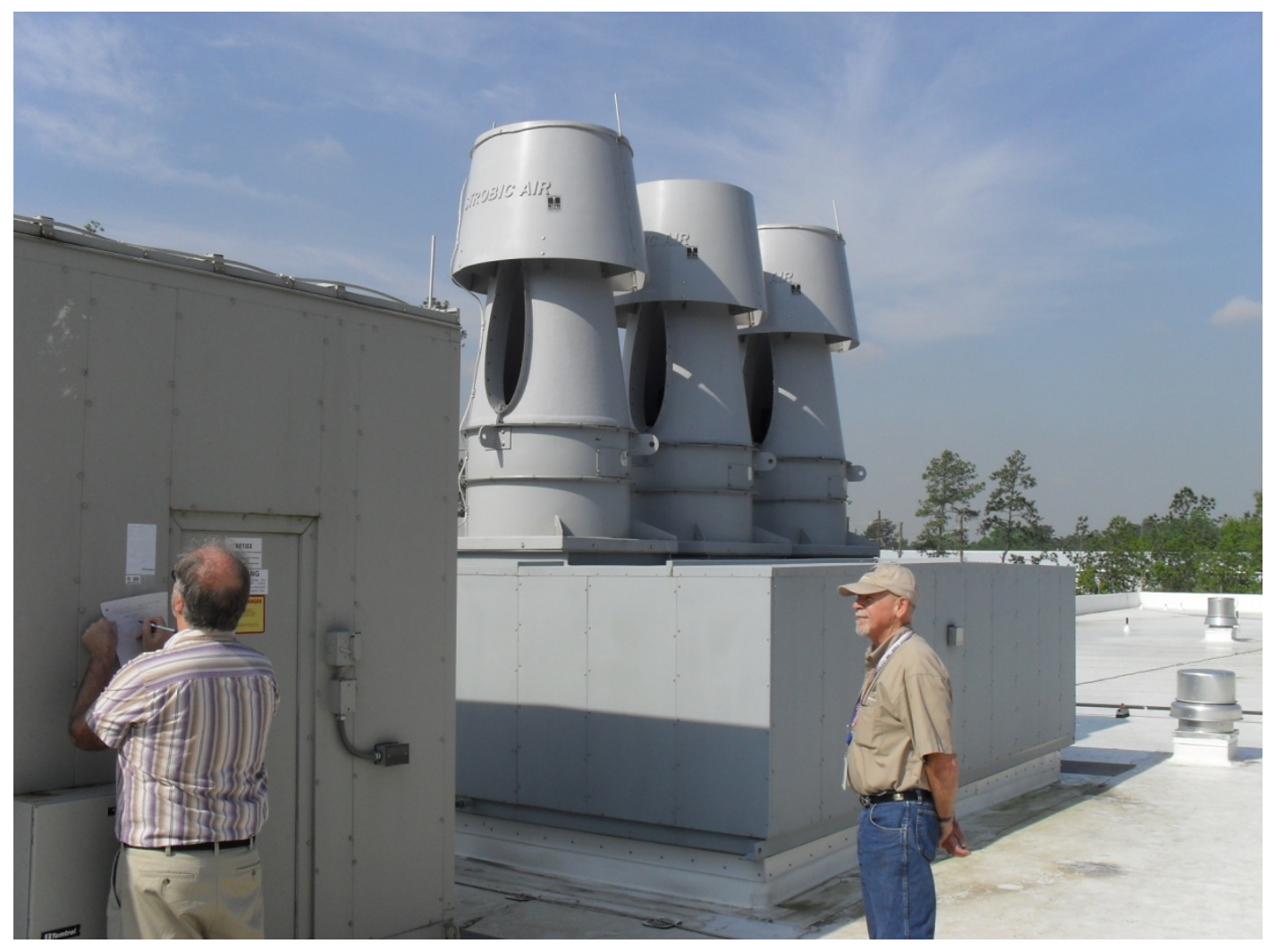

Photo 4: Jim Arends PE, CEM, Redhorse Corporation, and Bruce Chambers, Live Oak Gottesman, inspecting laboratory RTU during FEMP energy audit site visit April 2010. 


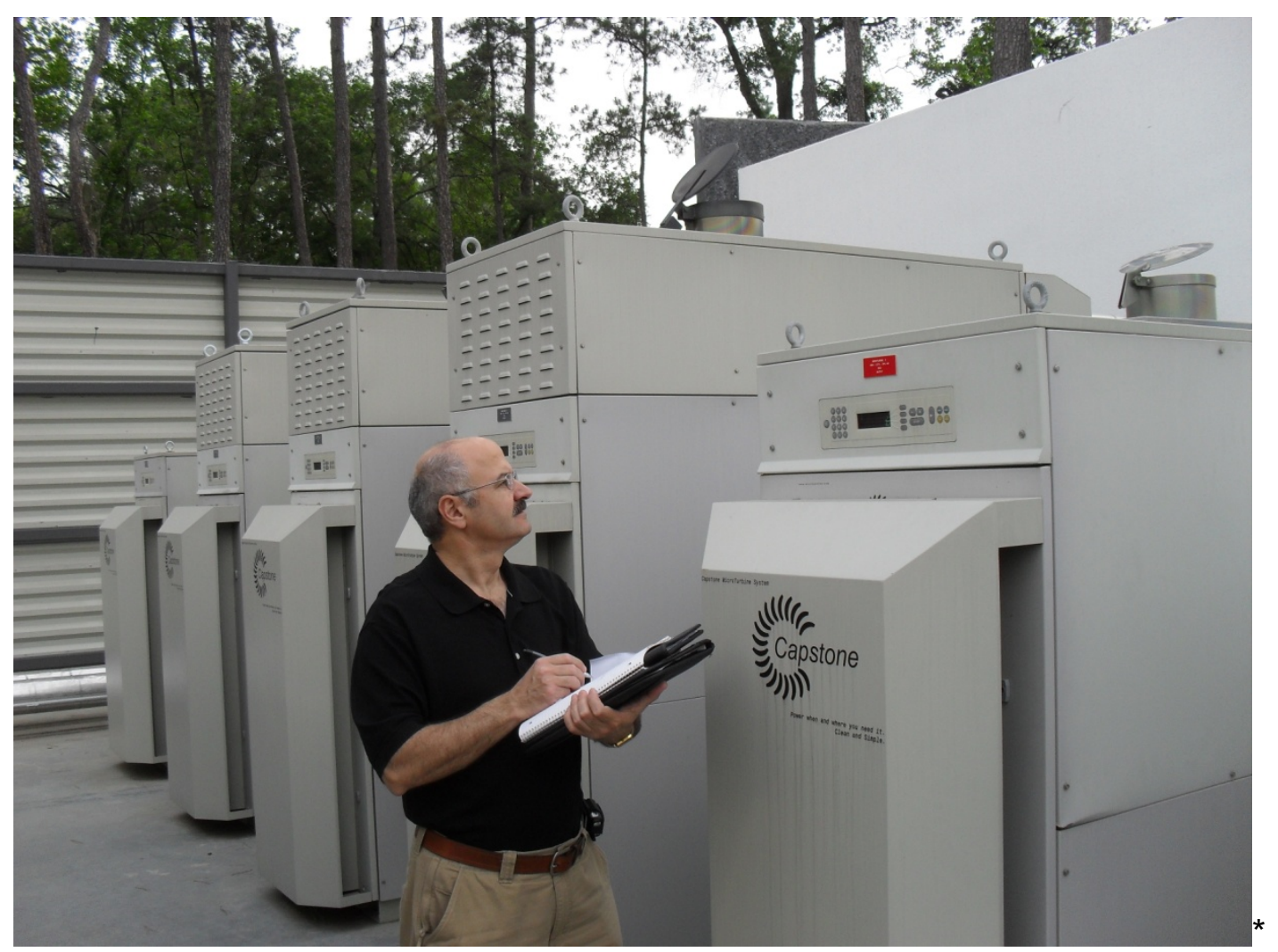

Photo 4: Hani Geeso, CEM, Redhorse, inspecting CHP Turbine Units during FEMP energy audit site visit, April 2010. 


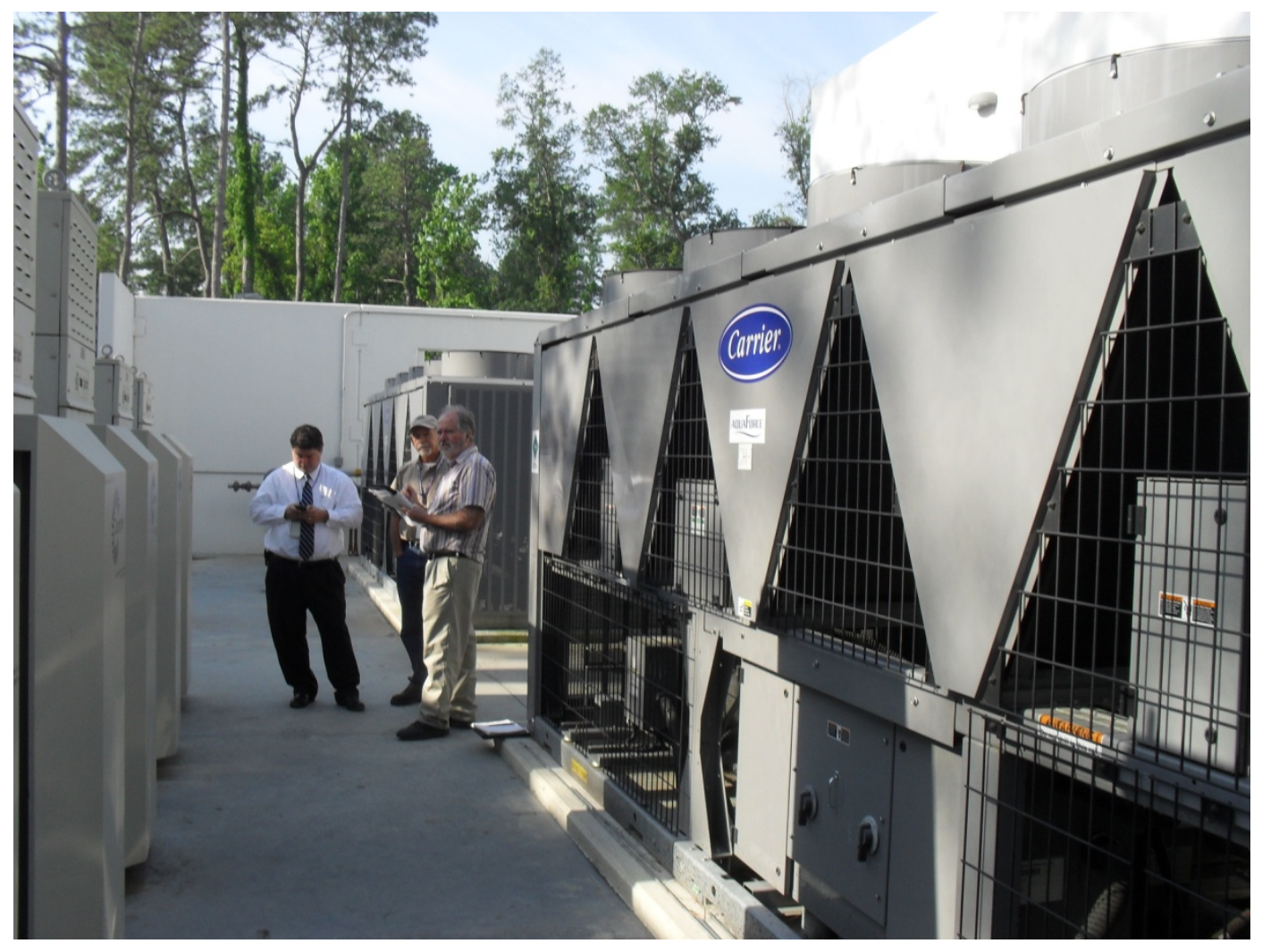

Photo 5: Randall Breaux CBP, Bruce Chambers, Live Oak Gottesman, and Jim Arends PE, CEM, Redhorse Corporation, inspecting CHP turbines on the left and the chillers on the right during FEMP energy audit site visit, April 2010. 


$$
\text { B-6 }
$$

